見 異くし 意

な常むたを文

しを帛のの払化

て個は染棁

る人異文き学 文常化たは

本集の精㔔文め

はと体医個化に般布分合類類出況り、焦

この視学人の

こ相を 城 境

数 互離 $の$ 界

年作 れで精を

来用たあ神定

過、る病義

急程徹。理 寸

速今. 底 文加る

芯志化らた

注兽た人出め

貝 相類発に

を, 対学し

集す主義文、異

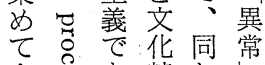

き ญ あ 精

た矿関の

文の。医心概

化産両学に念

精物者を逢に

神とは貫着注

は異地卜避自て異犯と異 常点 ラし身異常的し常 理し節 集 型型がの、集 論てし散が华個定異団 はいて型あす人義常が るいのるる打只の境 異。る 社。と占 (3) 成界 常だ。会そとび章の をと即立れ註集音定 扱方去はで団不義 うれ、峝三きのテ諸の 諸ば異極うる自山资た 学、常にの。己 の異のし葛そ防しに、に 間常類た藤れ衛 ぶは創 にの型、回に機ル、出 対表は二避は制集 (1) 卞 象現、元型 (1) 飞集工る 型集的の葛関団二有 方を団で社藤わ学》標

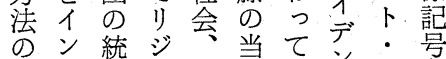
一デ合ッ葛事いン人う 貫ッのト藤者る、テべう 性ク類なを莫な的ルち

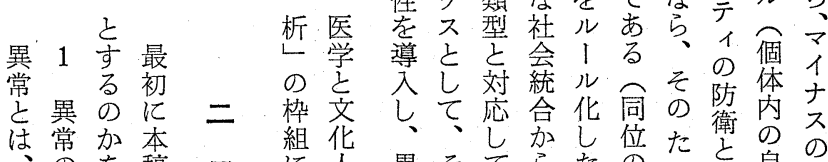
のを稿異に類裳え拈多さぬ維自サ

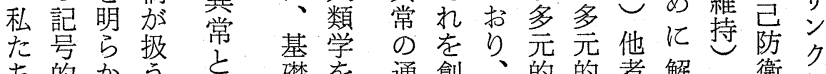

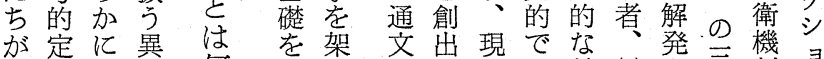

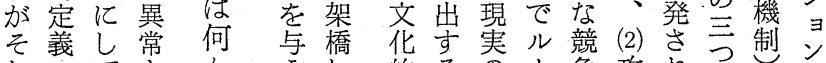

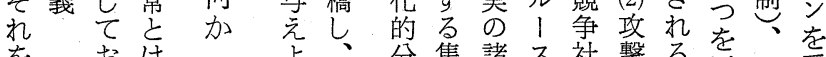

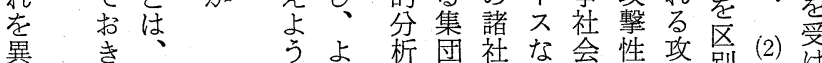
異きうる゙析団社な会性攻別間け 常

名

け な

た問

と 題

万仡

の に

の $\quad \frac{1}{5}$

あ゙何

る

何

之 象

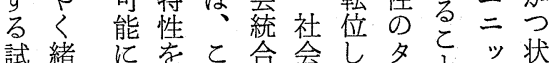

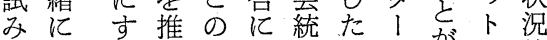

で着る論 ス至合フゲ㤎・的

あい。守ぺるを身ッてレに

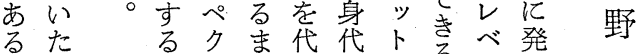

上

とトで償わがす。生 千

が厶、葛ので個る

で上統藤他あ 体あ

鶴

きの合を者る 間の、 


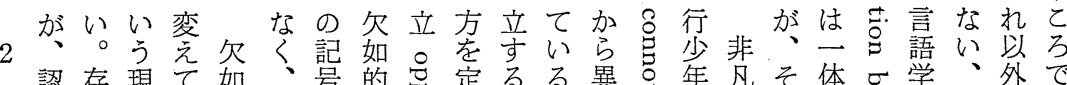

認存現て如、号的导定るる異年凡そ体年学、外飞者

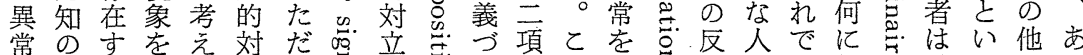
の網ると机立可の号け驾う差す意をは対の 機をあるばは異きうこる同いしす語考正立のとのすす

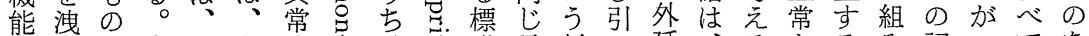
的れに名そもで主、㐫識示対い延、るとるみ記りてを 定る対称れ之な有壳差立た。善のはの合号シの名

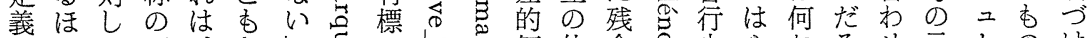


に明在一音との記引完值方と弆年さのうで差ルでる 自示はつ韻しで号も゙をはしだしだ説的のなと 明的:の論て市心总を持、ていいる。

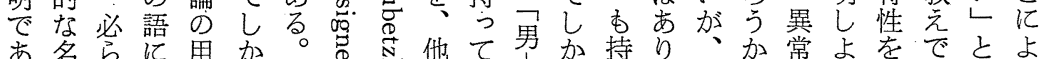

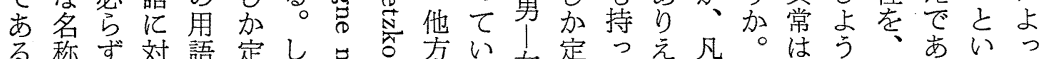

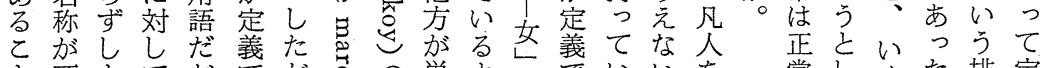

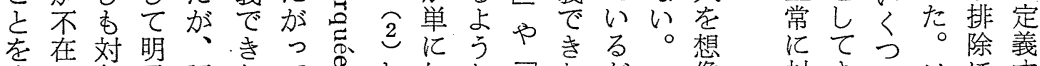
意で象示語なてのと次な高ながつ像対きかりにす

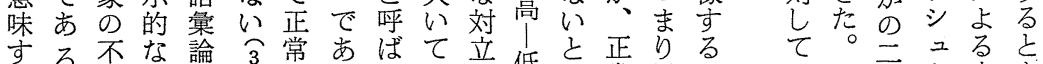

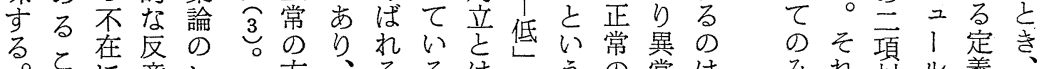
と意レ方、るるはのうの常は み枚儿義 とつ語べに正年異占性方の難定厄゙立以にそ はなのル常異欠な質は方し 義は立後よれ

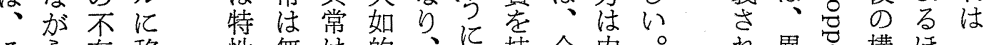

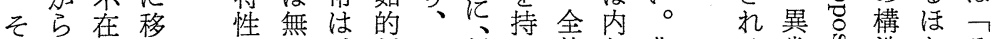
れなとし加標、対一対っ体包非る常总造加そ

あ有はイ有そるば、性断間り生を界て持な位でれ る有、ナ標れと、し 3 とに標れ守上、っ置あが語 天詒不記飞市加統創成分出るま当てとをる属の

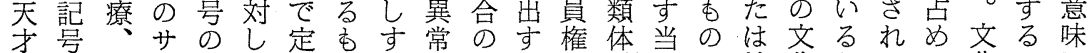
やの統ンうて義のべの維る系ので境化加てて化シに 聖中制クち示さのて心持と環が分あ界体らいい" 人に、シ、市れ同の理をと境害類る外系でるる社テ

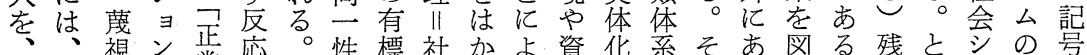

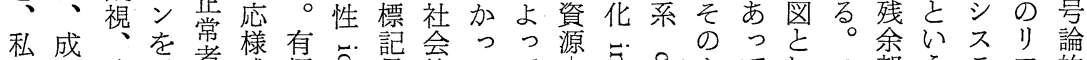

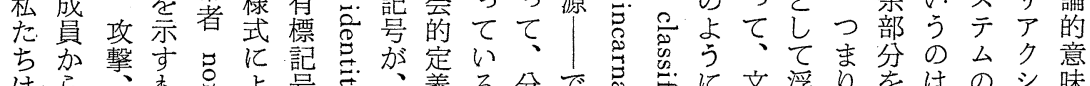

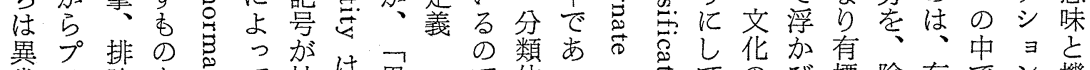

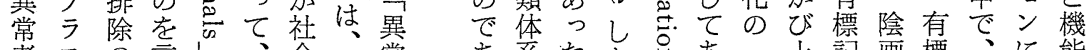
者スの言レ、会、常あ系たたすあフ上記画標、に能 との対う。当異的人常方文り社的境が号と記異よ論

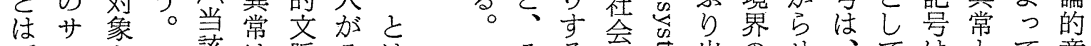

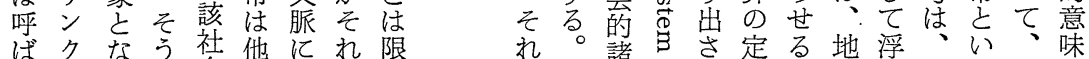

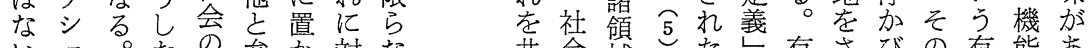
いヨ。たの弁加対な し、方多别れしい 彼受亡派李同心 らけし成るきさ理 をる貝。思態学 矯毛異人度に 正の異が常々をを しが常マはがとれ 共会域そた有さびの有能市

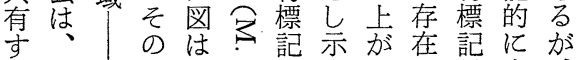

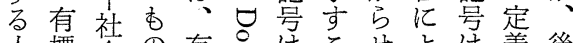
人標会の有名はとせせは福後 々記会で標和、とるつ、夺者 の号的あ記図に㗢て特るは、 同を時っ号文告き自別方 質不空たを出境うを明な法そ 


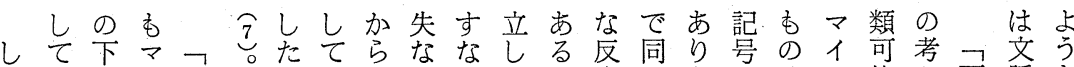

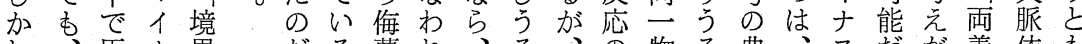
し、臣ナ界だる荗れ、る、の物る典、スだが義依す

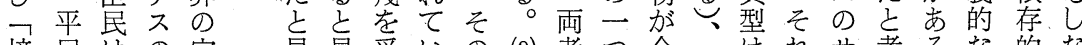
境民はの定見自受いの (3) 者つ全、标考るな的な 界は有義るるるけるとまはのく(1) だンえがっるい

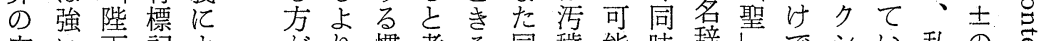

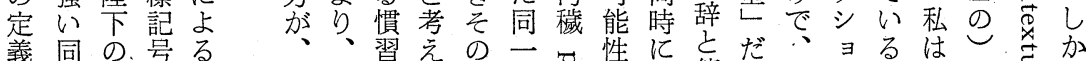

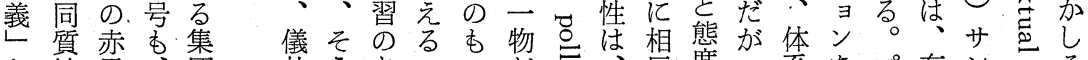

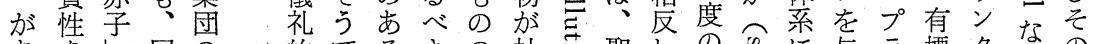
あをし同の’的でるきの社芯聖しの危に与ラ標クなの い獲とじ同現なとで一会る性たん゙きとえス記シすの違 ま得しょ質実いと貫的と居べミっらの号

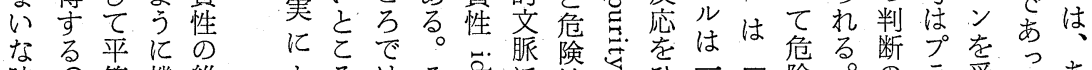

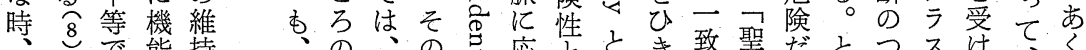

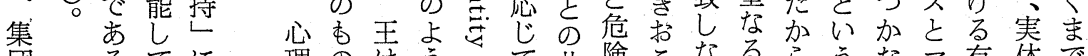
団るてに理のはうるるる有体で はしいは、的加実には異存性すいいでのいイ標的文

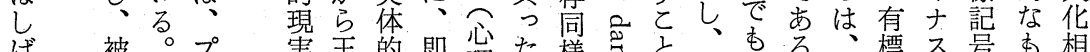

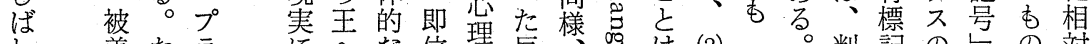

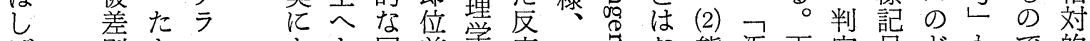
ば別と不市同前学応矛な態污両定号どあで的

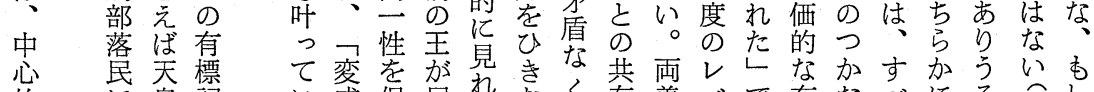

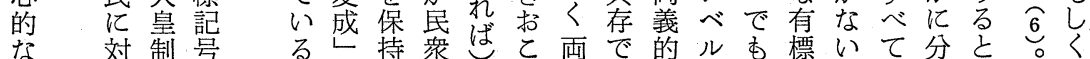

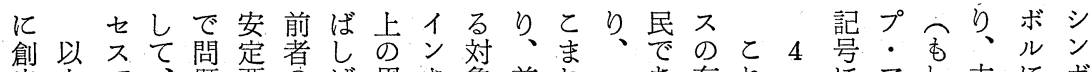
出上で、題要のば周さ象前れマあ有れれにアし古にボ 守をあ異に因例女縁れ都てイる標ま異訴イく代よル

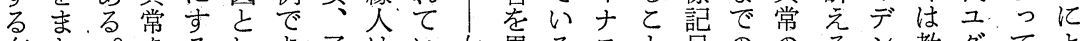

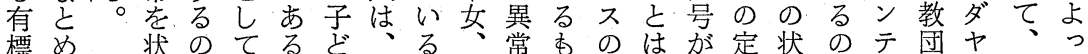


号定的、シ 被、況り人、は累標異で的あテのでりよ

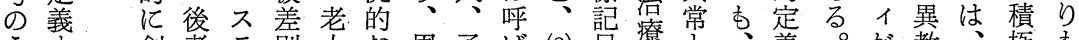
う寺創者テ別人な周子ば (2) 号療と、義。が教、極手 ち机出の公部之異縁どな状のやは異不的予的 、ばしケに落し常的あい況うや限常確要言に境

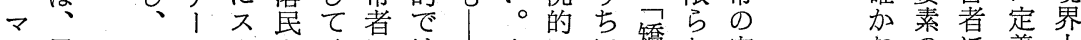

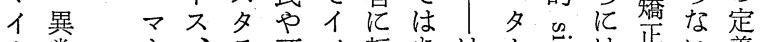

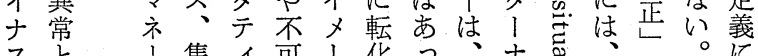

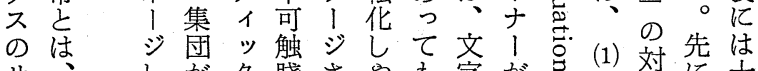
サ、しがク賤さや字が总制坟に十

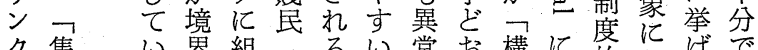
ク集い界組るるい常お構に等なげで シ団くのみ要全。无り造創的なたな

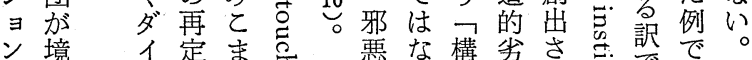

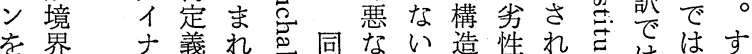

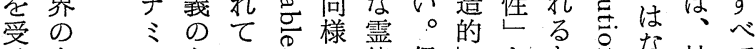

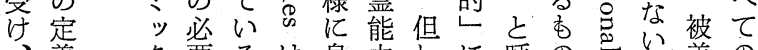
、義ク要るは身力㧴の气い。差の かのなに。分者、ビんとに別、 つた プ逢と構制は制ルでが組つ部イ 状め者と造あし度卜いあみま落ナ

なのに義上 時排よさの 撃るれむ 集さ信るし 団之仰。く はし復ウは ば現は1界 し象、バ外 ばしつ1の マたかが イ $\widehat{9}$ ね 指

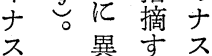
のグ教る・ 有 排之シ 


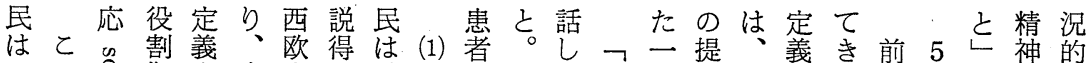

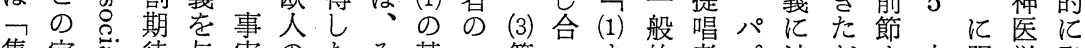
集定总待与実のたみ基一第つま的者プ辿驾ま文限学発

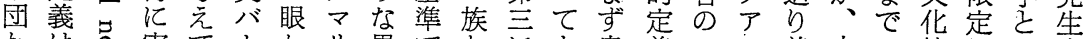

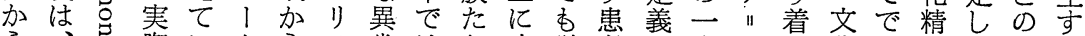
ら、务際いら, 常はち文説者は人二小化は神て接る

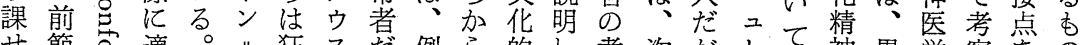
せ節吕適。”狂不だ例 ら的し考次が、て神異学察をの

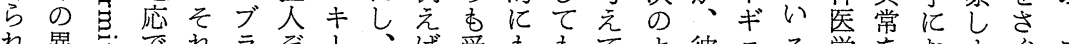

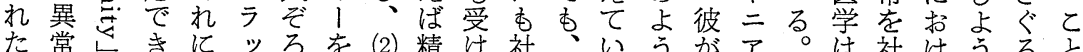

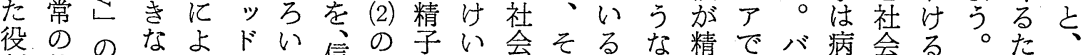
割状別いれレに信基にれ的のと娄神長 1 者的異めひ

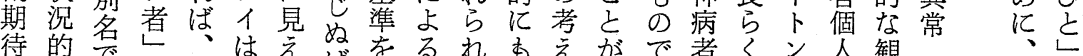

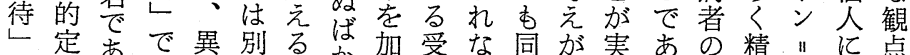
を義あ常なる加兴な同が赛あの精川に点

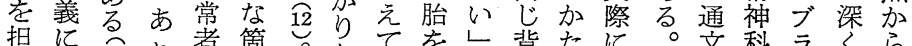

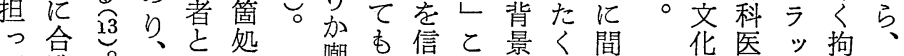

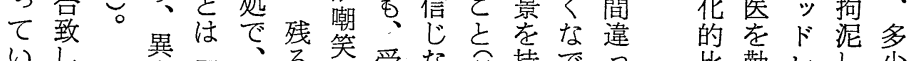

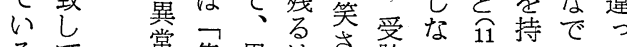
るて 常集異はさ胎い労なっ゙て

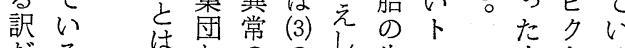

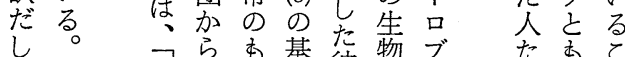

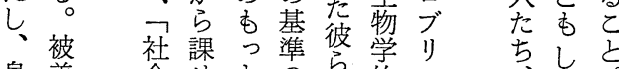

身差会せとの詚学少

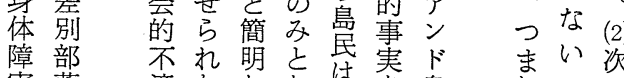
害落適たななは春島

り $こ に$ 比勤レし少 較め1つ之 中たす?市 吕文索同繹 金化様的 辿精古のに

(3) は文制! に人 ス (1) 人う亏迥管 テユ類いべし相は ム二学てリな互状 ・ッがはンい作況 レト研精 グ場用関 ベ・究神・合過与 ルレし病セで程的 べて理オあのな 集ルき学りる中概 団個を方、異念 の人言異詳常当あ 三十常しの事る 祘 (2) る者心相者吕 元間っ集方互作行異 区二ま団他用動常

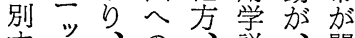
す、、の、説、関 る! 異正異は制わ こ $レ$ 常負常、度る とべのの者エ化 がへ成寄本スさ状 でル立与人, れ況

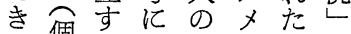
る個るつ心ソ役之 。間祘い理步割は た間元て的口期

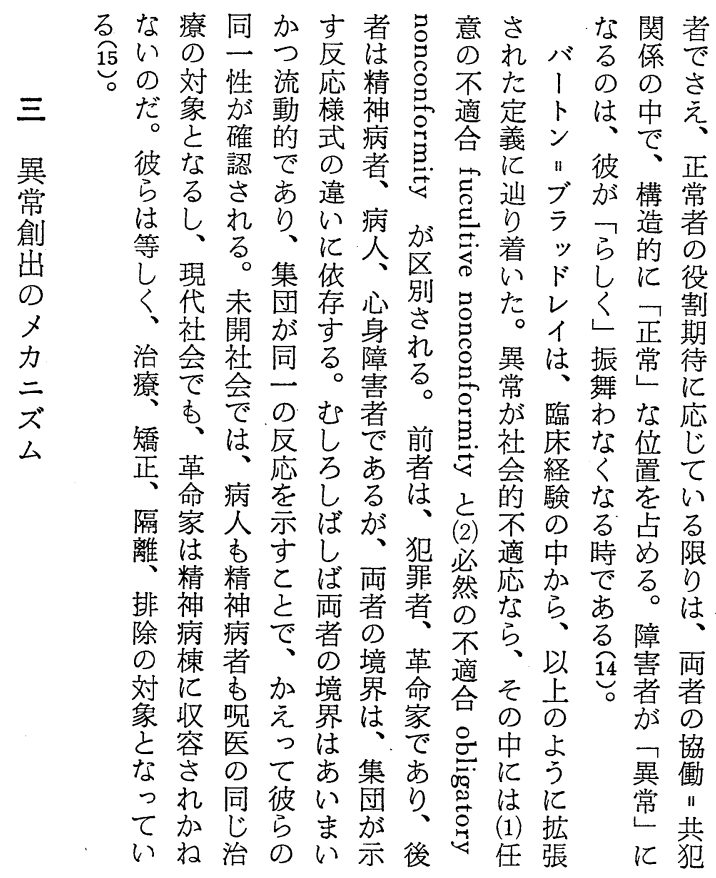




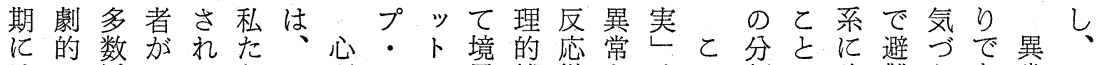
はに派マるちよ理ア・界機様とはの類で強難かあ常方 告示のジ葛はく学イレの制式い存う体、制さなるな次 発しコヨ藤、知でデべ危ははう在ち系既的せい。人元 者てンリ状社らはンル機、、概せ、の存にる はいセテ況会れ、テでに上(2)念ず(1) 方の再へ(2) ᄀし 通 被るンイの的て攻1は陥述?は、の分適キ眨認々底 告のサ、特葛い撃テ自つの (4) 消 (5) 場類応于貶知は卞 発は不異殊藤る衝、㞯た文に失の合対体さガ価的行る 者、を常性心。動の防分のあ場は象系せイし、不動論 の魔得者は.攻驾防衛類中たる合、にをる、例協に理

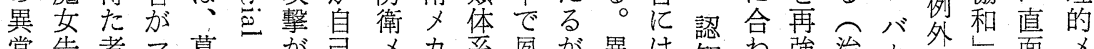
常告者マ葛驾邑丈力系夙汃異は知わ強治力視面メ 性発だイ藤』解防力三の、、常、の等华療と視のし力

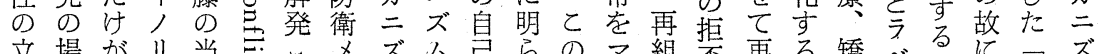

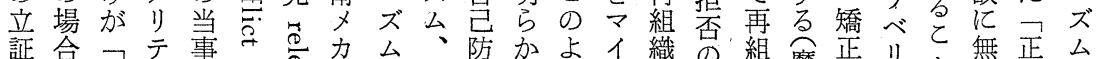

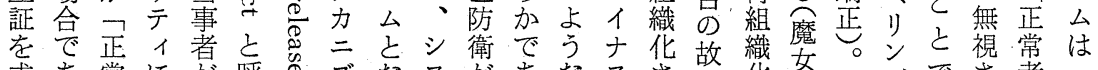

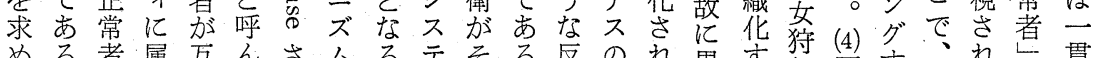

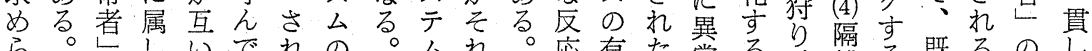
ら○ししいでれの○ムれ。応有た常 れ中でてにいる表

て世あい同る相わ のりる格が互れ べる、起号体い

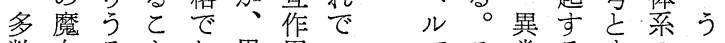
数女るとな異用あでそ常る市のる 派狩とだく常過るはれに論る中社 のりとあ、染程るこグは遭理人で会

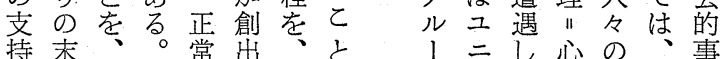
施離 る。存 設抑 (3) 分親る 収穴既類子応は 产、存体供は䒺次 (5) 除分を増のあ 既军 類 無 悪とる 存る体傷に的。

的血て女とし動攻 プだメム、か ま縁低やにり的撃その出力へら異 1 た原い異よあでをの社、ニパ、常 は理統常つうあ物一会そズ、治の葛 三で合者てがり理つがのムソ療創藤 重あ水は、、、的はあ前でナや出回 単る準発葛決メに、りにあり矯は、避 系とで生藤定ン回ピう、りテ正、型 的言満しは的バ避グる異、ィのその とわ足に物な1专ミと常と・よ社 言れしく理破相る门とにれシうへ会 うるない的綻互夕のをるかスなの よがけ 17 に的バ指つらテゆ攻 り、れ 、そば滅るにでドし攻作まや 正れなそ立前葛あのて撃業たか 確さらのるに藤るよお性ははな抑

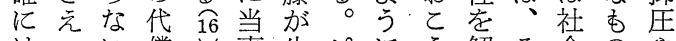
は、贯。償事生ピにう解そ会のや

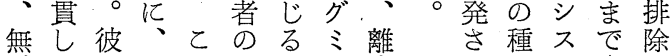

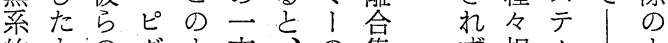
的向のグよ方穴の集和相么 台 との統ミう加互バ散にを在う 言で合门なバいン管類が通な うは原社社ンにド鬲む型自じ暴 べ理会会ドロはか化己て力 きいは始を污成に、う方防、的 で。はる衛シな

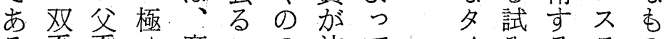
ろ系家め魔この流て イみるテの

ばが織わ転を 共化 らし 熾 異にのなて烈 四常: 必け異に の分要れ常争 概 類にばのう

異念体迫な烙一 裳之系ら ら印方 常のがれなをの

あ選て 類功可るう机者 型消能となると 之失な言社側な

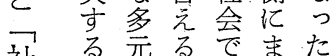
社る元るでまた 会衣告缹分。正

の.な択著類告争 類る肢の体発い 型。の立系者に 一場は驾敗 つ既自れ に被にらた な告動 正告 ○発摇統 発 て者し争者 しのていは ま立再に え場組加一 
に会現顕つゆ位るきせ社ら者に伴こ得ば会た

組実在フでる型社エるる会は、市わのしいる心屯。

分織の型ラ高や会ソ。と主競ぎずよたメ㞧理う

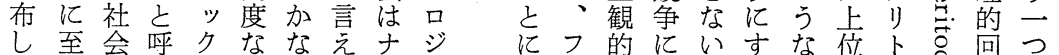

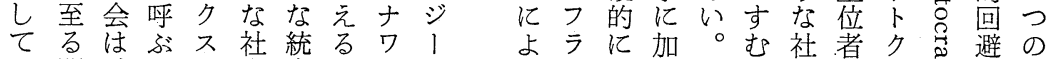

い間、乙型会合。バのつッは競よ会㤎ラ气型夕

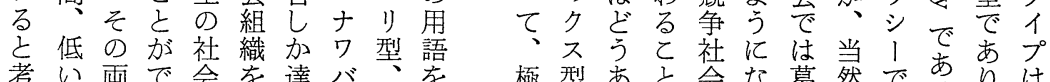

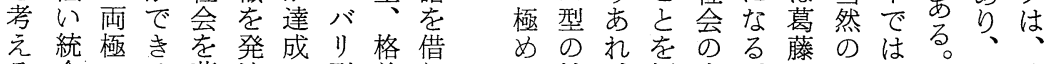

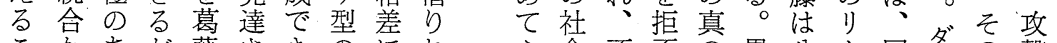

こ吕あが藤さきの机会不否の異公! 同名の撃

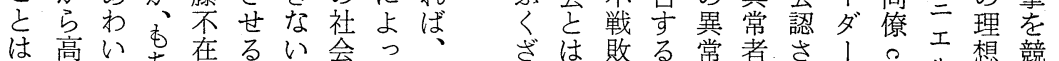

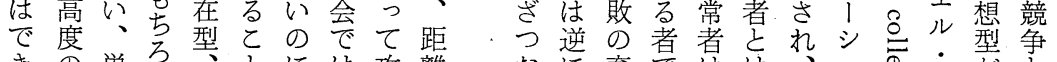

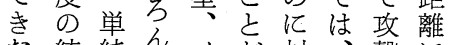

な統純再メ㤎対撃任

い合な南りでし、個をよ

だ水社者卜き、体心っ

ろ準会極クる順の理て

う組極亏全位接的攻

か至織端シ型触に撃

。る加な、少を回を

ス 理型社制避物

ペ 念の 会限守理

クく型社要专る的

卜ざに会、る社に

ラつず会

㕕な窇

ふた会回

くめは避

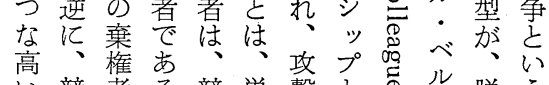

い競者る競単撃とた掉脱う

統争に架争に性応の描産形

合原卞主競 の分支々業で

度理芑競い争解の持と社ル

ををな争う社発報にろ会

達多い原ル会は酬よろにル

成元。理 1 の、をつの来化

要的このル落異亭て来るし

るに組多で否者の受正像ぎ無

とみイは認の創る性に能害

上社ず藤 ざに順市

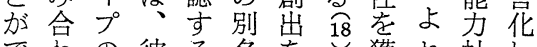

図 1

Grid

system of shared classifications

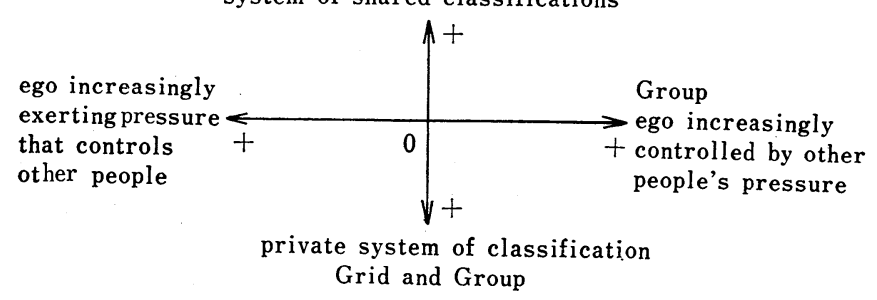

社で完 類

会䒠全型 ダ

第他二华 グ

高方元る

限分爷み

類、に社

で体個、会

ま䒺人一の

ががつ統

異完社の合

常全会解度

はにに答の

発多統をス

生元制与 ペ

し 的さえク

にでれてト

く佂

い個くるム

現方て図

実社 1 異

の会る

社統社 $\underset{20}{ }$ 創

会制会。出

は会分第

、第類加

乙自象体 ら

の 由象系め

座な限等て 


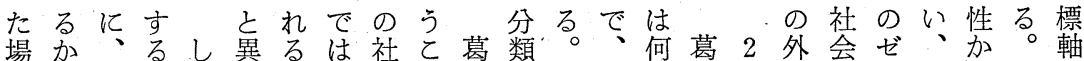

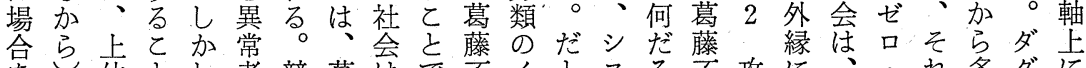
专位とし者競葛はで不イとスろ不攻に、・れ多グに 別者が成は争藤、あ在ンすすう在撃、とポは元ラ分 工別にで員生との葛り型デれムか型対そのイ分性不布 ゾは対はき間しい当藤、のクばの。か象れ図ン類にに 口刘向るになう事之そ社ス、自異らのぞで卜体よ、 シ象け名格いル者のと会に何已常葛スれはの系分れ第

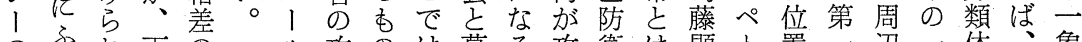
の方杂の攻のは葛る攻衛は顕卜置一辺一体、象 用加ず位あの撃を、藤に撃の、在ク守象につ系魔限 語著る中性物葛顕違のた葛型ラる限扣のの文か でえ攻のよでは理藤在い夕め藤にムとのいあ多告ら 転 ら撃 攻う 位尔性撃な

○。性社

は、的は型な、にを至 当に同のいゲ攻回る 勝の消位社。ッ擊避 ス

攻東は会

者競滅者会 と争さ間の 敗 相せの共 者手る葛通 はもが藤点 生萎草は れへ藤る成 て向顕。員 屯、在葛 の 正解の不等

れけすす け者 はらでた抑 常発社在と 卜性 す ペ にがルク 選解儿尗 れさ化么 るれあを 加るで分 と対き節 い象なす うのいる とと状口 交衣況 ジ 者さ会型い、市中ク
考外てり元発第 え縁で方性㤎言 ら访ある゙性活象 る葛 2 万化

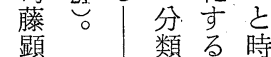
在そへ体の間 型しの系は軸 のて推の、に 社、移不分沿 会葛点在類 つ は藤を体て 第 不座意系移

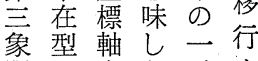
限の上な元す

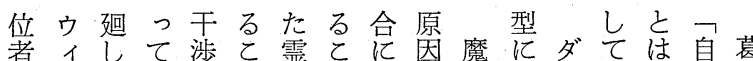
間ッ者は孛とがとはが女分グいで巳藤 のチとじるはシが、(1) 信加ラるきか不異 そはしめ訳なンで共古仰っスとなら在常 れ単ててにいボき同見はてはいい当型の とにの、は。リる体え、い類 な競ウ特い(3) ッ。はな異る魔了ろ他葛型 り争イ定汃ᄀク (2) 犠い常へ女イう者藤と 、相ッさな敵につ牲ウな図告デかま影社 つ手チれいの被排者イ事 2 発、。で在会 いした。党わ除をッ態存をア攻し型の に寻で攻 (4) 派れさ出势 $\overparen{23}$ 論は㨻のの類 はこは撃フのるれさし説。じ、性異両型

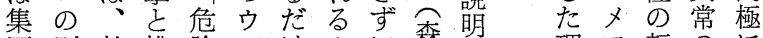
団別敵排険 1 ウ の名は除なッでィ集精る論り位スま 分に十の逸千、ッ団精因的・のぺた

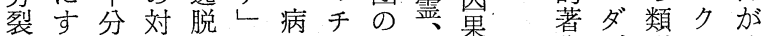
にぎ象者の者しア祖仮作グ型トる

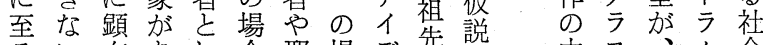
るい在あし合邪場デ先説中虫公 こ。化らてに術合ン雪— とこしわのは者にテにつ がこて机ウ特は個帰 2 るはるる。特人病イせを゙ 葛た (5) チ定排者をらあ 藤め孔とき质に回れる はに敵にてさ憑復るが 同、のなむれい卞場
でに集をの 負団対 魔っの応ぺ 女て統さク をい合せ卜 五る度てラ つ。にみム の 対るに 類 応 こ
であう者攻動 きる他を撃の る他は見性儀 者な出を礼 小自化 そ。分 れとと占 がうがり 転しで弱 位てきいき し攻な他宫 た撃けの 身のれ七の 代夕ばト二 わ鬲行く種 のッききる 他卜場豆る 者ををに 22 め失転。 自ぐう位も 自て攻省 身、撃方 之葛性法の い藤はず選 う当自る択 類事目。肢 型者へ犠は が管向牲 


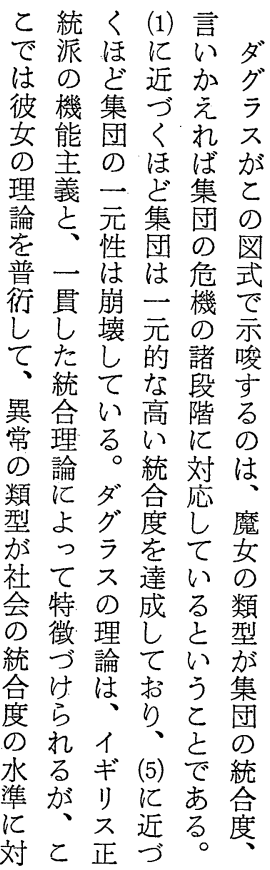

かとが異わ応

二に゙るを少る

”た媒つ占

トなし介たう

・違た門な

认 $ら$ 方題

ベがそるに集般

ルるは団い的

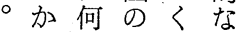

(3) シ 加統つ枠

ゔ希そ合答を組

いテし力完構

うムて二な築

イ・そズけし

ンレれムれて

タルは、のばみ

ラル文な

ク。魔うらう

シ（2）女だな

ン誰告がいそ

- 異驾々(1) に

プ常達れ魔は

口者成以女

七它守外告彼

スなるの発女

をる統方は㤎
ख 2

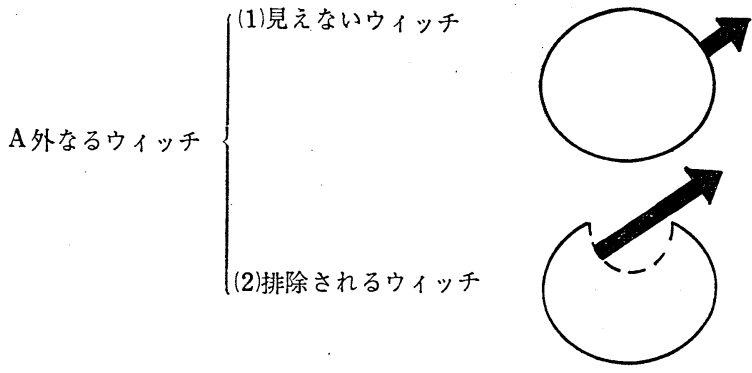

(3)敵の党派のウィッ



(4)危険な逸脱者として てのウィッチ

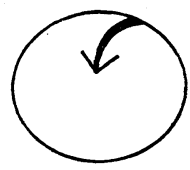

l(5)敵の迴し者としての

$$
\text { ウイッチ }
$$

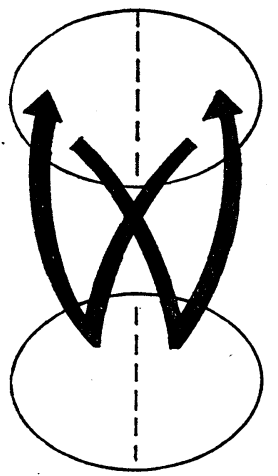




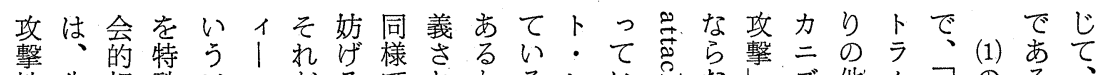

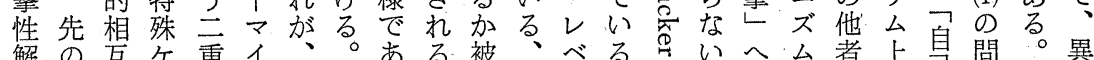

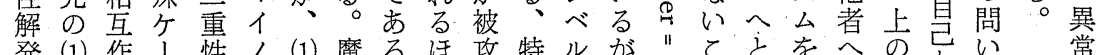

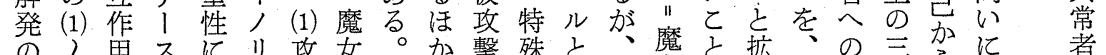

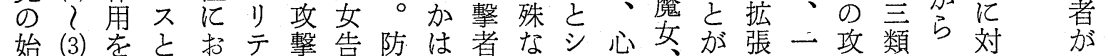

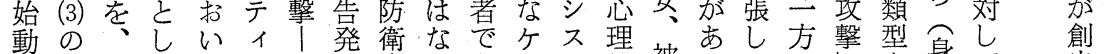

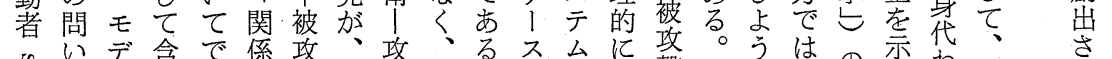

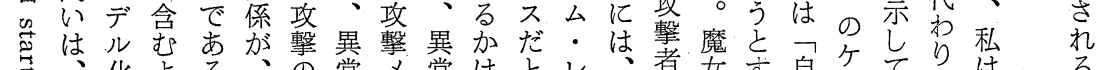

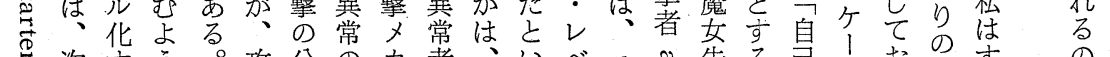

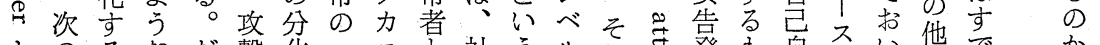

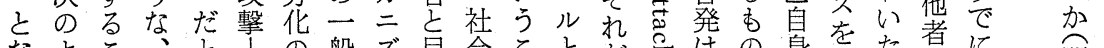

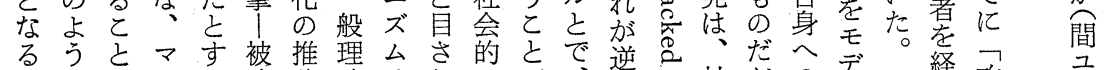

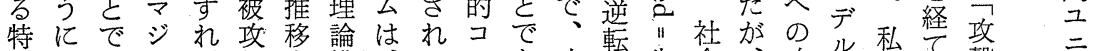

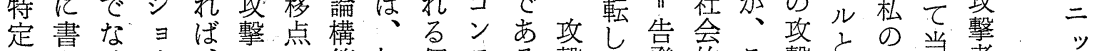
のきけリ、の筑加個テる撃て発的と撃し試当者

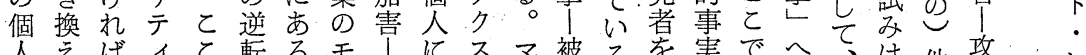

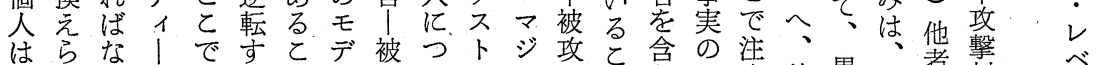

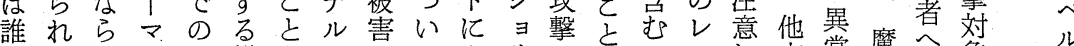

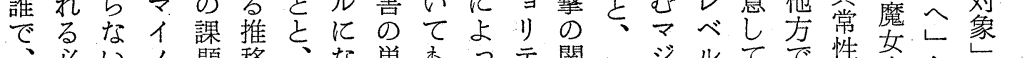

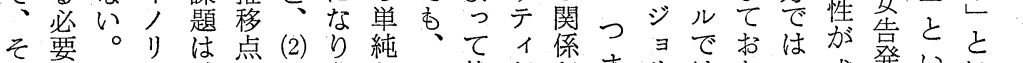

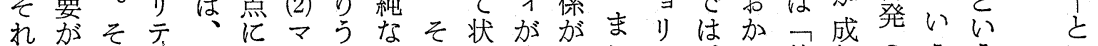

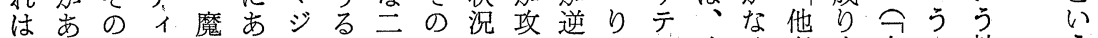
なるた間㚣る、の極事的撃立二イ攻け者立身之軸方

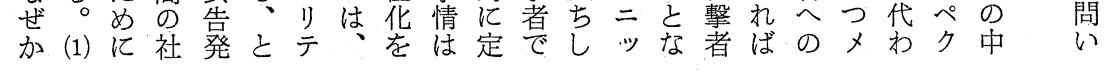

図 3

\begin{tabular}{|c|c|c|c|c|}
\hline 攻撃対象 & 例 & ユニット・レベル & 間ユニット・レベル & システム・レベル \\
\hline \multirow{2}{*}{ 自己 } & 病気 & 医学 & $\rightarrow$ 医療社会学 一 & $\rightarrow$ エスノ・メディシン \\
\hline & 精神病 & 精神病理学 一 & $\rightarrow \quad$ 家族研究 & $\rightarrow$ 文化精神医学 \\
\hline $\begin{array}{l}\text { 身代わり } \\
\text { の他者 }\end{array}$ & 魔女 & $\begin{array}{c}v \\
\text { 心理学 }\end{array}$ & $\rightarrow$ & $\begin{array}{l}\text { 文化人類学 } \\
\text { 社会史 学 }\end{array}$ \\
\hline \multirow{2}{*}{ 他者 } & 犯罪者 & 逸脱理論 & $\rightarrow \begin{array}{r}\text { ラベリング } \\
\text { ・セオリー }\end{array}$ & 統制理論 \\
\hline & 革命家 & $\leftarrow$ & E & 変動理論 \\
\hline
\end{tabular}

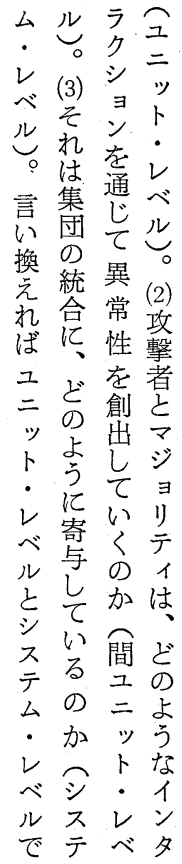




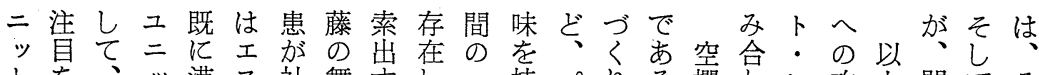
卜を、ッ漢ス社舞守し二持パりる欄わレ攻上問てそ . 集登卜方ノ会台るて貫つズは。にせべ撃を題間れ アめ場・へ・関と機い性とル矢暫てルノ整とユぞ プてすアのメ与し能ながしゲ単印定得/他理な二れ ロいるプ関デ的たをい理たはなは的た間者しるッ個

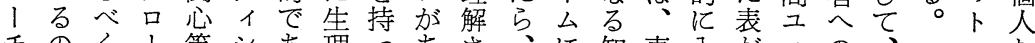
チのく、等 シ あ理っあさ、に知専入が二の、掠

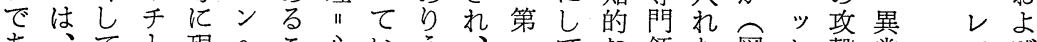
あ、てと現へて心いう年ててな領た図卜撃常べび る誰登シ象のと理るべ対にあ八゚域の3. 等の集

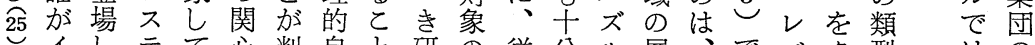
○イしテて心判自己研の従分ル展でべタ型はの ノたムいは明己で究綜来にゲ開該あルテ告攻ア

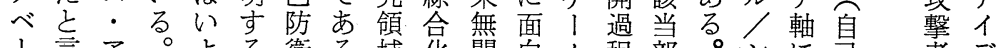

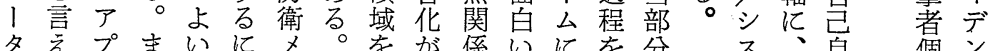
夕えプまいにメ。を驾係いにを分不自個ン

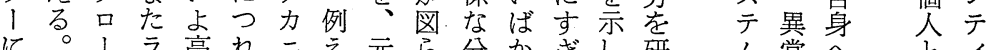

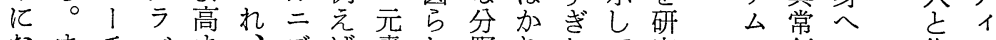
なまチべま、㢳素れ野りなて究・創の集テ るたのリる医㕕病る息加いい対レ出攻団々

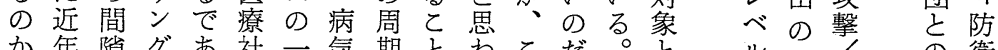

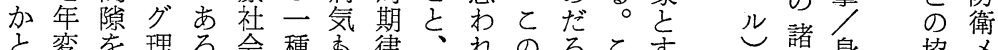

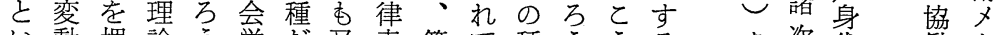
心動埋論う学だ㕛表第て種ううる。次代働力

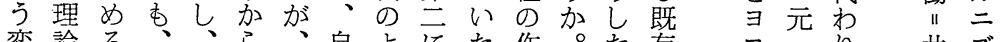
変論る、、、自よにた作。た存コこり共ズ

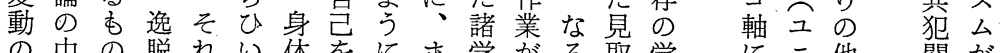

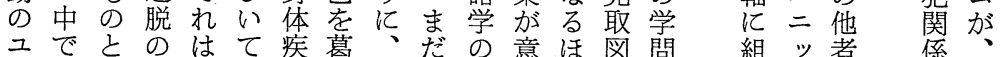

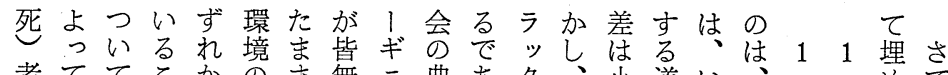

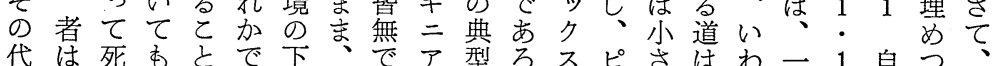

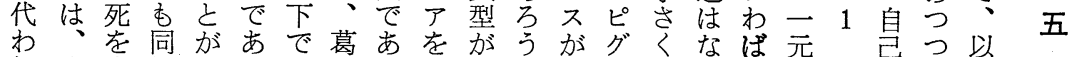

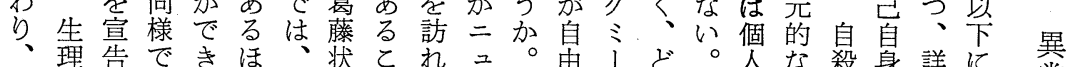

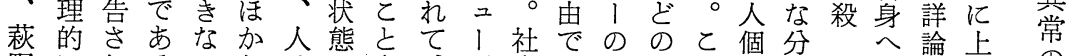

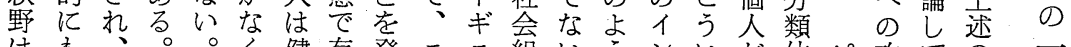

は恶し一そく健存発二三組いうンいが笨ピ攻ての 一

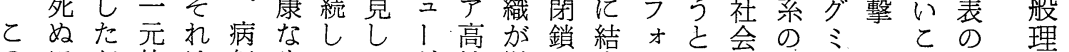

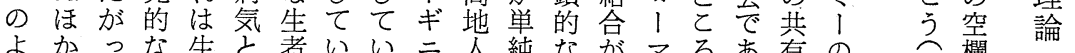

よかっな生と者いい二人純なが、ろあ有の図欄諞

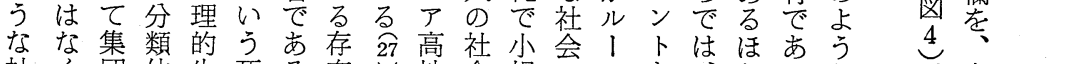

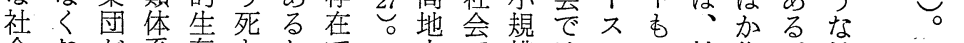

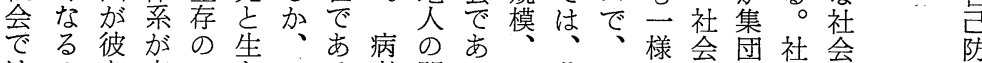

はの支の亡そる者間るか葛かなにの会で会衛

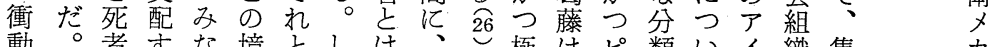

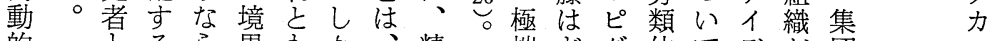

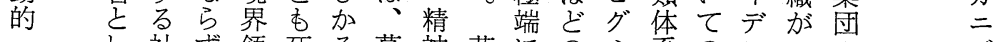

発し社ず領死る葛神萩にのミ采のンルの の゙

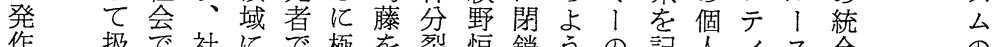

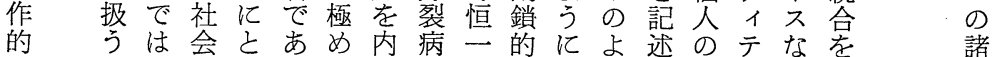

な的どるて在とはな処う卞情々と保相

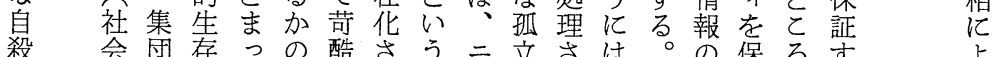

殺会団存っの酷さう二的ににて立さは病二社れフし偏証でる 
図 4

\begin{tabular}{|c|c|c|c|c|c|}
\hline 異常の類型 & 典 型 例 & ユニット・レベル & 間ユニット・レベル & システム・レベル & 社会の類型 \\
\hline \multirow{3}{*}{$\begin{array}{l}\text { 自己自身 } \\
\text { への攻撃 }\end{array}$} & 自 殺 & $\begin{array}{l}\text { 自己破壊による逃 } \\
\text { 避 }\end{array}$ & $\begin{array}{l}\text { 不特定の他者から } \\
\text { の侮辱とその内面 } \\
\text { 化 }\end{array}$ & $\begin{array}{l}\text { 集団の同質性の維 } \\
\text { 持 }\end{array}$ & \multirow{5}{*}{$\begin{array}{c}\text { 一元 的 } \\
\text { リジッド } \\
\text { 小規模 } \\
\text { 無 限定 } \\
\uparrow\end{array}$} \\
\hline & 分裂症 & $\begin{array}{l}\text { 妄想への逃避によ } \\
\text { る自己防衛 }\end{array}$ & $\begin{array}{l}\text { 相互の役割期待と } \\
\text { 役割取得 }\end{array}$ & $\begin{array}{l}\text { 集団アイデンティ } \\
\text { ティの危機と維持 }\end{array}$ & \\
\hline & $\begin{array}{l}\text { ツキモノ } \\
\text { ヒステリー }\end{array}$ & 劣位者の欲求不満 & $\begin{array}{l}\text { 一時的な役割愼倒 } \\
\text { と地位上昇 }\end{array}$ & 集団の再統合 & \\
\hline $\begin{array}{l}\text { 身代わりの } \\
\text { 他者への } \\
\text { 攻撃 }\end{array}$ & 魔女告発 & $\begin{array}{l}\text { 告発者による不安 } \\
\text { の投射 }\end{array}$ & $\begin{array}{l}\text { 多数派の支持と魔 } \\
\text { 女迫害 }\end{array}$ & $\begin{array}{l}\text { 悪魔扱いによる境 } \\
\text { 界の再定義 }\end{array}$ & \\
\hline $\begin{array}{l}\text { 他者への } \\
\text { 攻撃 }\end{array}$ & $\begin{array}{l}\text { 犯 罪 者 } \\
\text { 革 命家 }\end{array}$ & $\begin{array}{l}\text { 正統化されない順 } \\
\text { 位のフラストレー } \\
\text { ション }\end{array}$ & \begin{tabular}{|l|} 
下位者のルサンチ \\
マンの緩和または \\
統制
\end{tabular} & 競争ルールの維持 & \\
\hline & & (攻撃者の自己) & $\left(\begin{array}{l}\text { 攻撃者と集団の } \\
\text { 協働=共犯関係 }\end{array}\right)$ & $\begin{array}{l}\text { 集団アイデン } \\
\text { ティの防衛 }\end{array}$ & \\
\hline
\end{tabular}

維ス破、壊い号面い他をの 28 は当し例 ラ 己には多

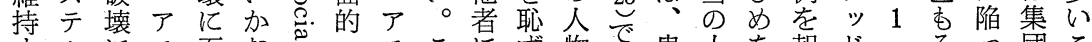
す厶にモ至なきょモとにず物で患人を報ド・らう団と

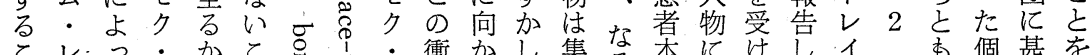

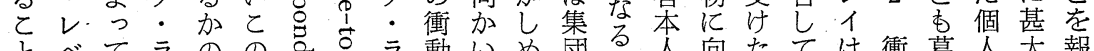
とべてラののこ余ラ動いめ団る人向たては衝葛人大報 とル自ンいよの怘ン的、たのぼが加い動藤はな告

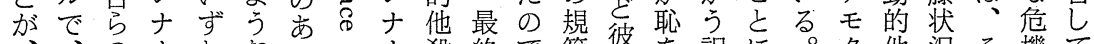
、、の! れなるな! 殺終で範彼を訳に。ク他況そ機て み集アの加社と定をは的あを特成で起ア・殺それをい ご団イケの会々住生、にる代定りは因モラ特る とがデ।道でで社じいは。弁定立な产クン強く。 にそンスしはあ会るわ自だし個たいる。ナ同の制た二

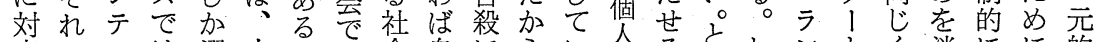

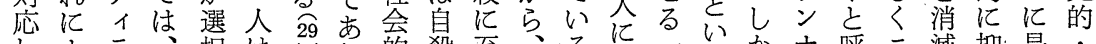

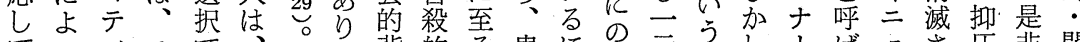
てっィュで、、背的る患にの元うしはばュさ圧韭閉 いてを二き完固血景他ほ者高の的の患がれ る堅防ッな全定縁の殺汃のぎるな省生るギるるす的 。固衛トい菂を特で、攻ずら規恥の百衝三ほ加避な なし・の適な基徴あ彼撃、机範驾攻る動了加、社

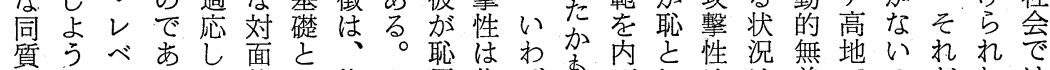
性とルるて状し均辱集ばす面しはは差でのがねは

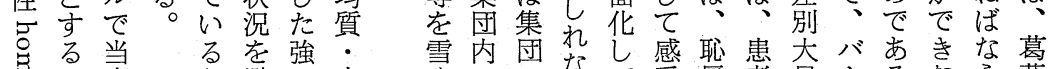

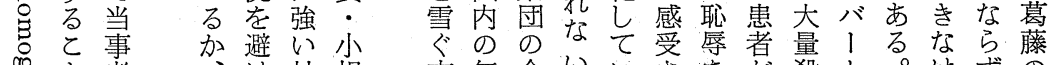
品者、社規方無全いいすをを加殺卜。けずの

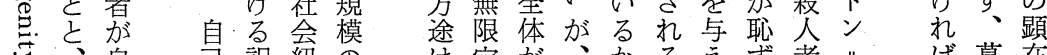
学自訳紐の掟が、加るえず者川 をシ㞯破に帯対なな彼そらのたがのブ自藤化 


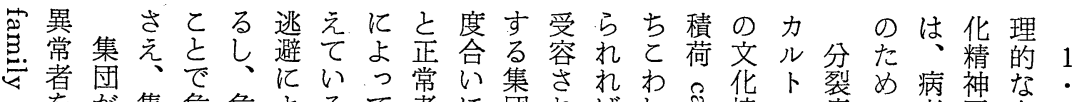

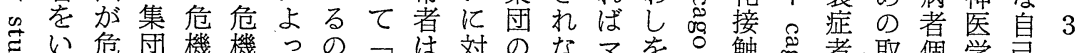

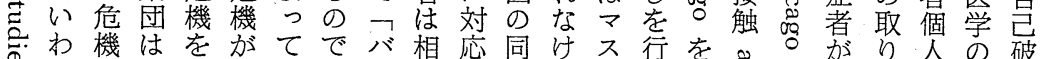

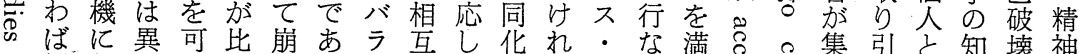
で析頻常視較壊るンのてのばヒう載こる集引と知壊神 あ出し者化的に 31 役い程、不行し至ま尃き社見で分

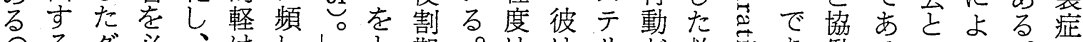

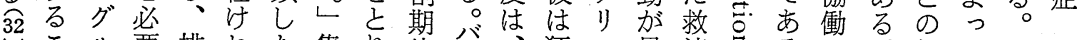
こと要排れた集り待 バ狂了見済るる。相て分

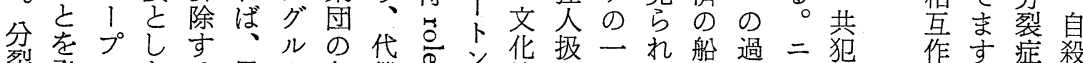
裂発・たる異1 危償のン接い種る抬程二関作す症殺

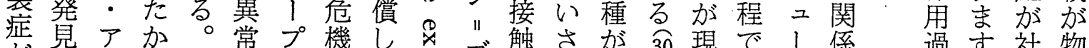

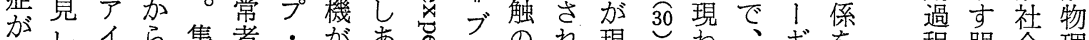

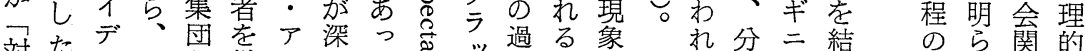

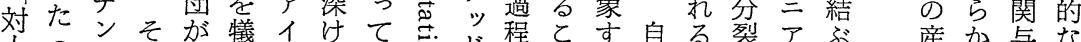
人のテれ異牲デれグ号ド程と方貝る裂了ぶ 産か与な

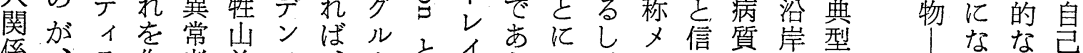

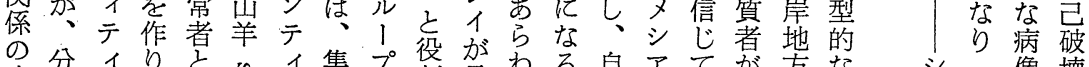

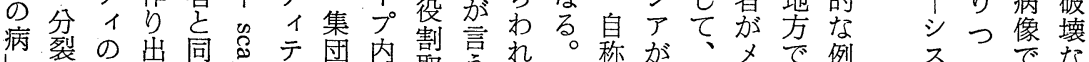

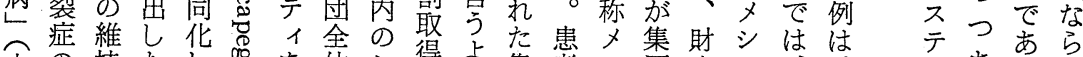

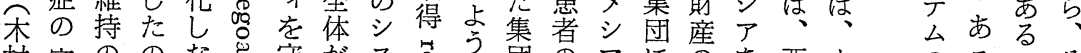

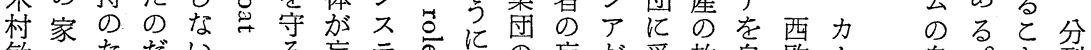

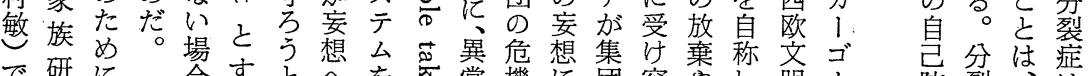

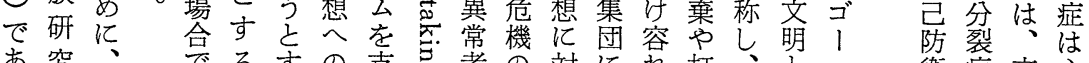

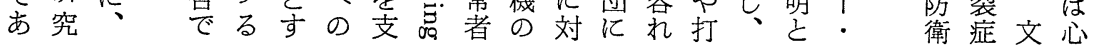

いにそ質性族よいった偽る衛をデこちすどらそンる

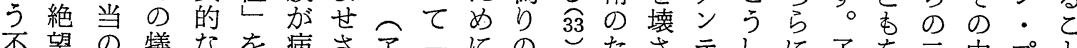

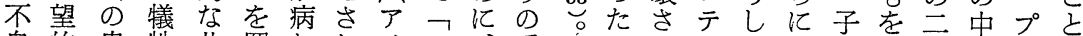

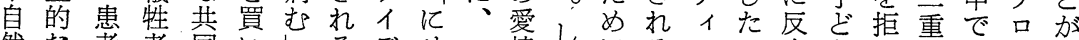
然な者者同いしる。゙せ愛情加にるテ主応す否拘大七知

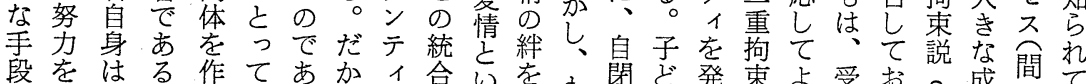
段をはる作てあが合いをを閉ぞ発束よ受お枋成間て にし、場り

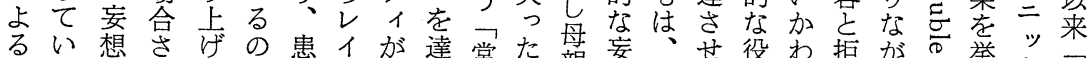

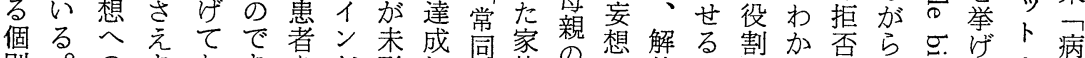

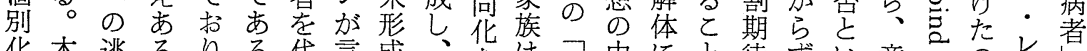

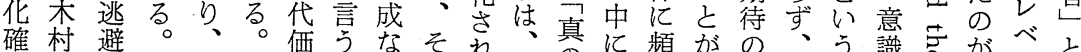

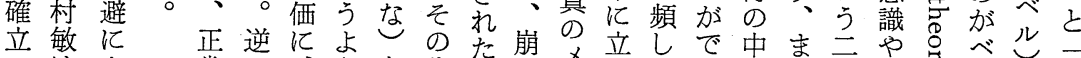

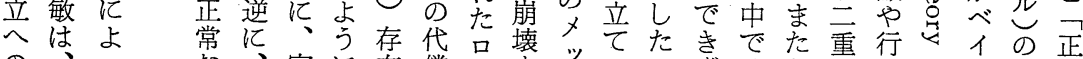

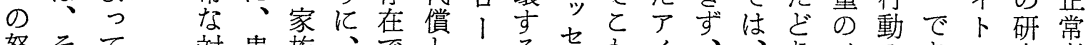

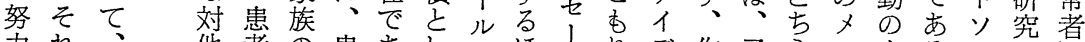
力れ、他者の患あじ、ほ

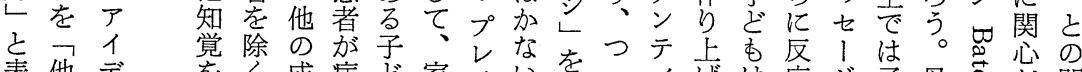

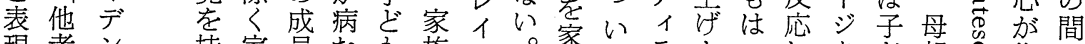

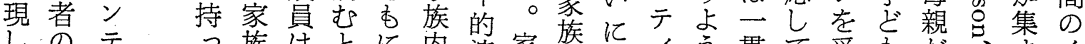

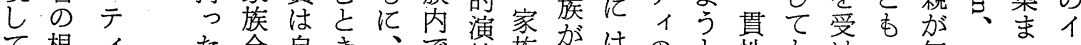
て根、た全自き技族公はのと性す讨へ無レさン い本テ患体ら柔手技公分絶しの罰取の意々て タ

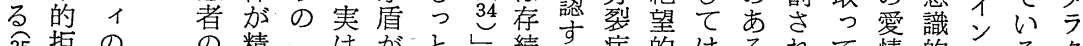

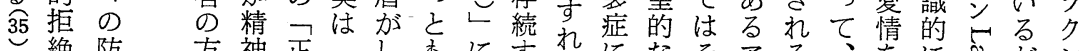

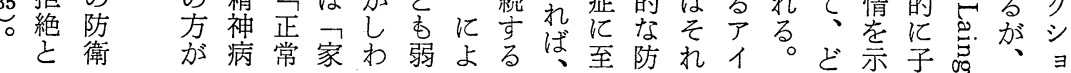


シなと市るフ範はあ優れりをる3わわ化のに人るな

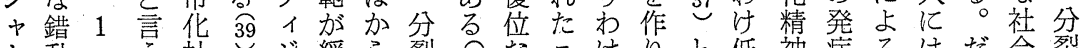
1.乱・う社活ジ緩ら裂 38 な二けりと低神症るはだ会裂

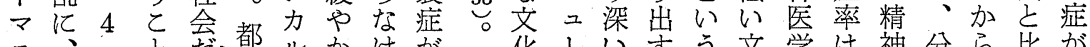

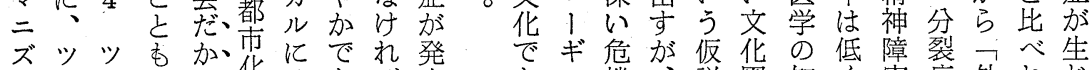
厶キキでら、化はあば生辛三機、説圏知く害症外れじ のモモき他会、るな要るるをそがに見、のの来ばる

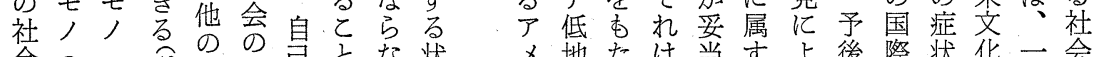

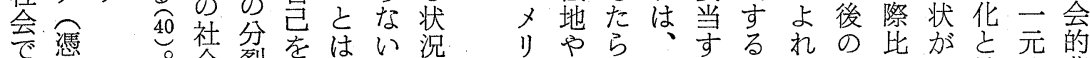

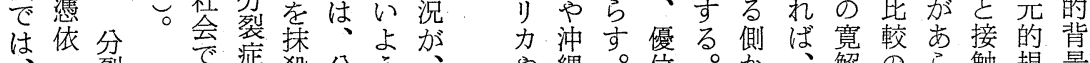
裂発殺分う縄。位。加、解のら触規景

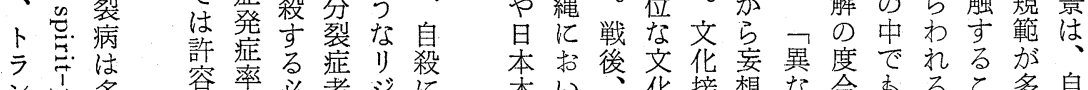

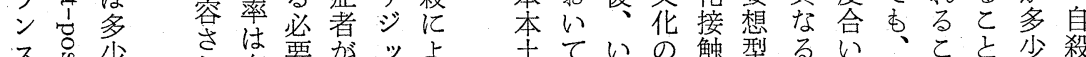

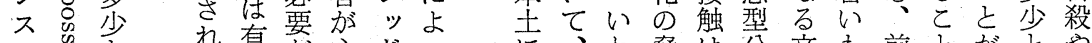

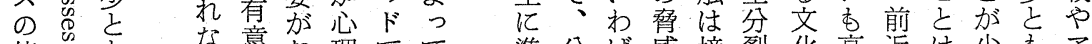
能息息な理でて 準分ば威境裂化高近は少す了 力等持高的二自拠裂否に界症のい代ほな緩モ

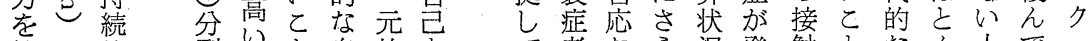
持や的裂が息的市著なら況発触となん人で.

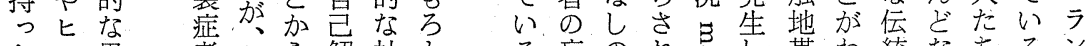

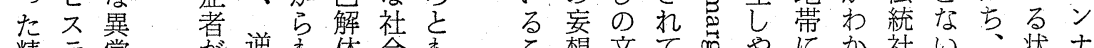

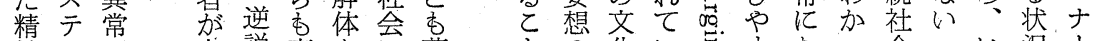

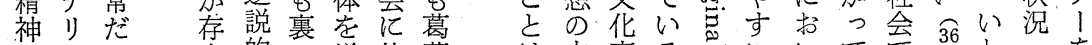

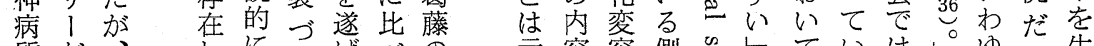

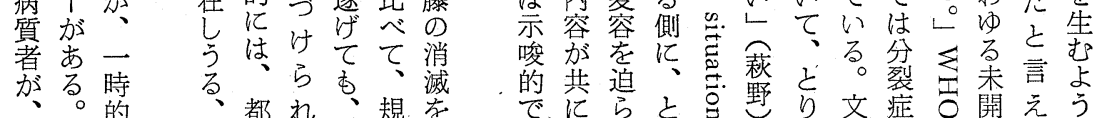

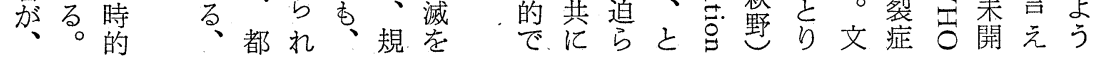

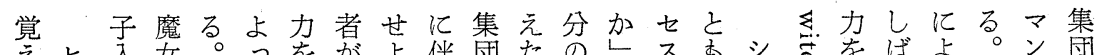

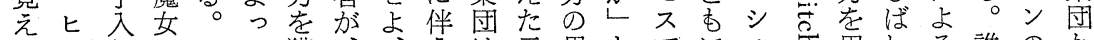
たスらのアて獲、方は元男とでに中字用しる誰の加

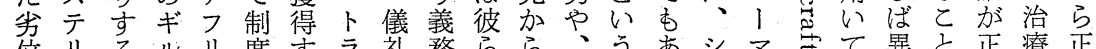
位りるルリ度すラ礼務らら、うあ 者、のドカ化るン的やをの父問るスンに旾常が統対統

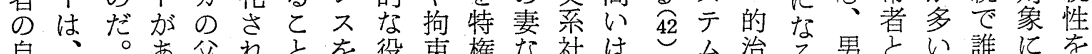

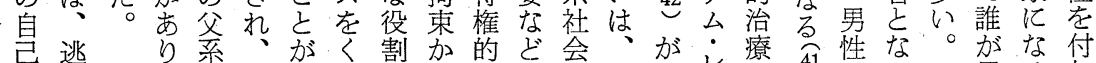

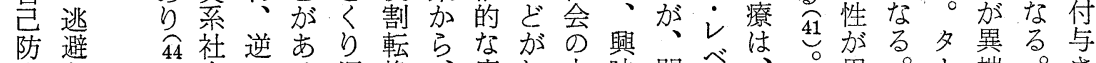
衛変会にる。返換、病し中味間べル、。用。１端。さ

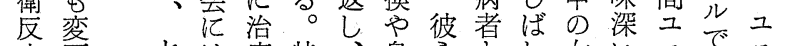

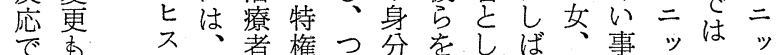

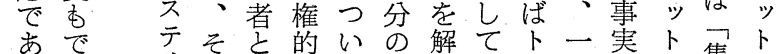

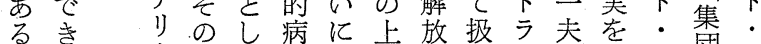
。な のよて者は梨しいン多示レ団レ

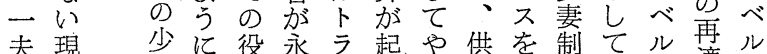
多状女し割続ンきる物伴のいで適で 妻に枯てを化石る范う社るは応は 制フ、特与古を。捧七会。马患 のラ彼権えるコ味牧不身誰占者 社不的らとンをそたテ分㤎市の

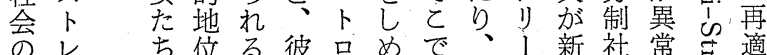
のレ妻। はシあ獲うはル特二分陷い会に点で 、ョと得う集す権時やる妻低なし市 夫ンへしに団る的的役がをいるプる がを弟たなに能病に割、迎身の口と い例ナ加持れ れえ।は続れ ばばの、的ば 呪ア言当なシ 術フう人病中 少構 の者 1 の 的力治ン 父劣に療飞、 に系性よ者 社をる、に異 女会付よ転 常 性で与り化視 がはさす吉さ 用、れるれ い同た社とれ れじ人会とば ば超々的とシ 邪自は属あゃ 術然、性あ। 


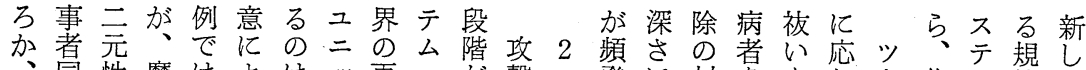
同性魔はよはッ再・架撃発に対ををじキ集少範い 魔土は女、っ告!定レあ性身し見象抹卞てモ団1の妻

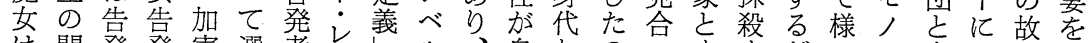
は間発発害選者べル自わの方夺だ冬に自よに迎 当で者で者ばのルにで魔己りはてるるるけで陷分っ、方

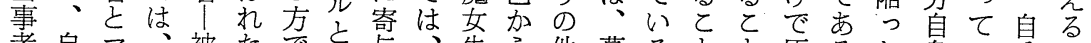

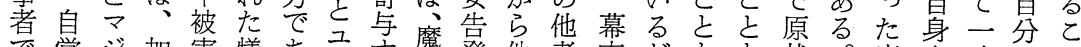

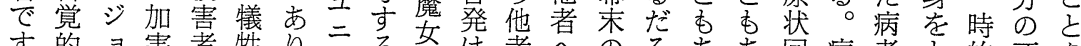

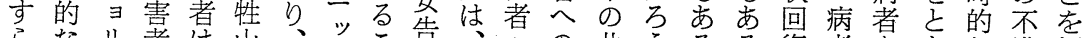
らな者は山山者崖発々向の共うるる復者老すな満拒

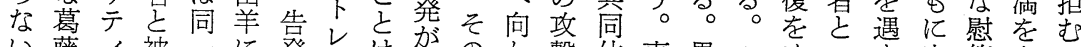
い藤イ被一に発心は要の加撃体事異ッぬッ守籍自乙 只がの害人すさル、魔微う解実常キざキるつ賞と

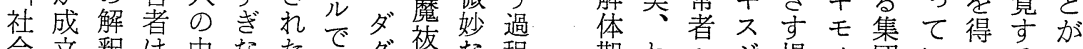

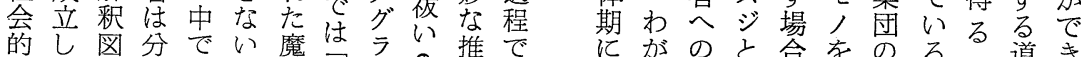

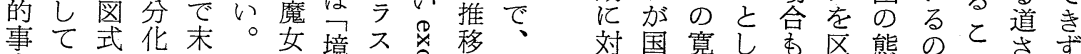

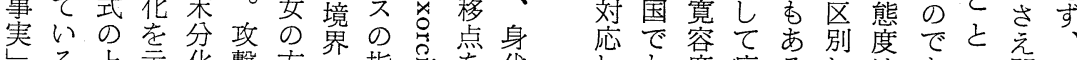

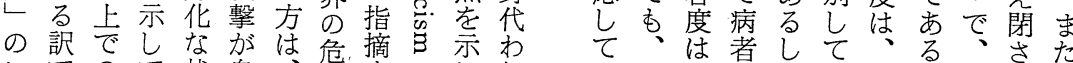
レでのて状自、機守をしりいッ者して、集る制れた

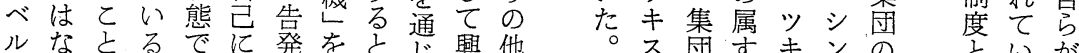

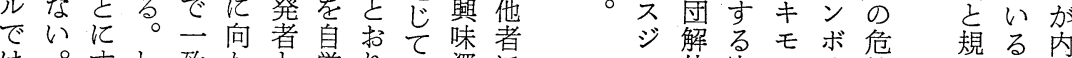
は。すし致加覚り集深者 そぎかう集华だ集い軽 魔れずして前団しがの。位 女ど、そい節のて、、シ 安 がこ当のるの合い間境スる

へ体家ノリ機

の の系当ッの 村危をろ ク度 八機立に合 分の排毛厄い
規る内 範。面 の彼化 崩女 女 壊はて か ヒ

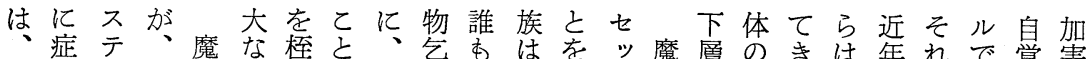
前例リア尘要梏で彼认拈共雄り魔層のきは年れで覚害 者が!フ告求と、はをん同弁不研つ機いで魔攻閴化者

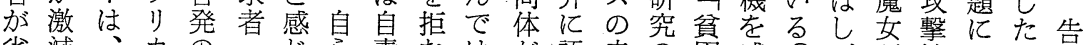
劣減、カののじら責むは珸未の語感尔ば研性な集発 位す停の活る始のの者な養っ亡中層受等究のる団者

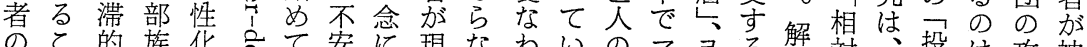

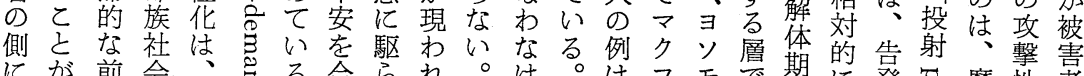

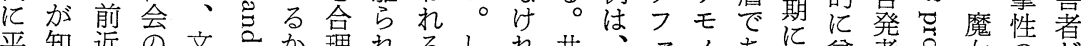

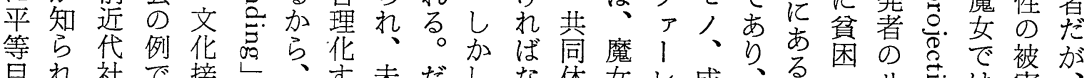

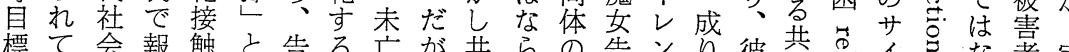

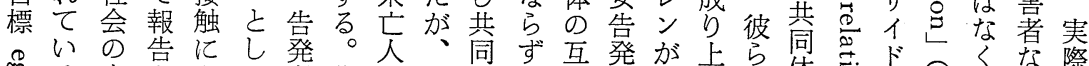

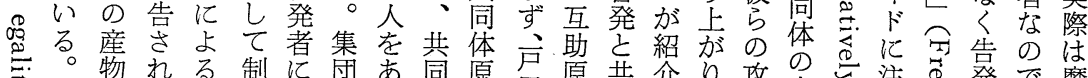

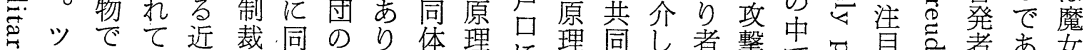

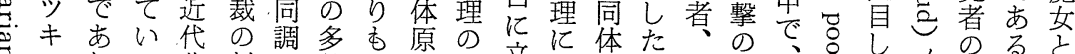

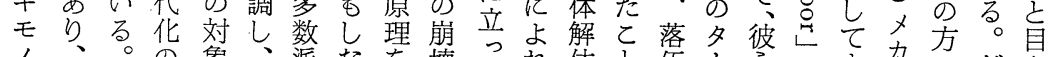

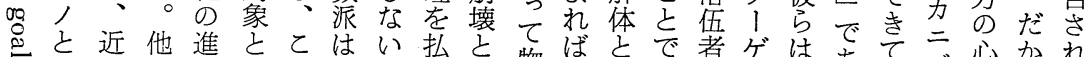

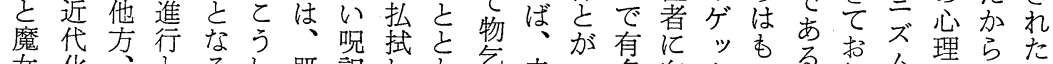

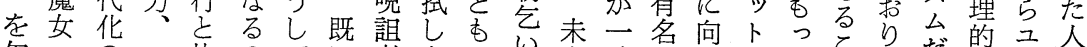
欠告のツ比のてに者きに、す亡致なけはととと、だ機二物

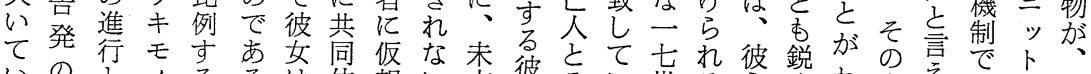

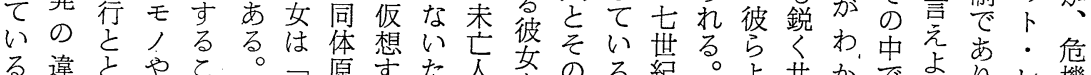

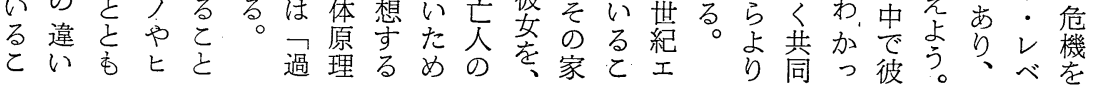


図 5

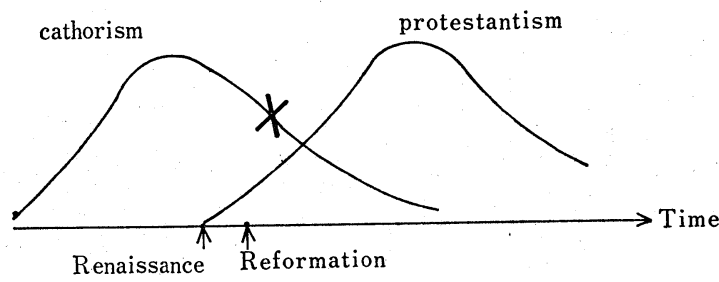

X：魔女告発の活性化
二 元めすれ嫢值と

元暗に平て範がて

的黒、等 なのよ化た体面る キ中りが下が化 $\widehat{46}$ リ世苛進位崩さ 。

スヒ酷行者壊れ。

卜にな守のにてッ 教よ異るフ頻いキ 支り端。ラしるモ 配字審逆不つが が、問にトつ、の 動中を、レ市魔生 摇世必規、る女じ は束要範シ立告る め゙に、緩方爷起会 、す加活。きは 加な言け性そる 衣方た化の社あ 言方吕社しよ会い てソ事はそなはわ プリ実、の社、ら ロジ魔自た会内面壬 テ公住防には面二 夕之告衛ま抑さ的 ンい発の类圧れな テうはたまさた価

統会当っそ場規とガ的障現人業罪飞守の性ィ 化はしのての合範二 3 しテ・害在々社者、・同よ化ズ

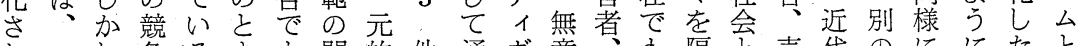
れユし、争るき市間的他通ヴ意す隔去壳代のににたと な、、相。に灾な者っな図老施離い春社形、なのい い下競手葛は告コ規へて形的人設方う婦会の新ろでう 順ピ争コ藤魔発ン範のいで非に収る新、会異しうあ新

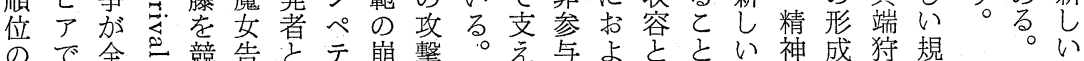

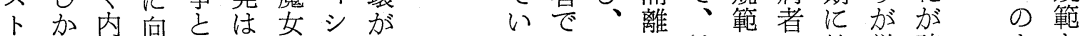
レな面讨い対のヨ進变との社にが精㛜確よあ ス心的らう等論ン行企る机対会な共神し立. う形 を。にれ形な争が泉業とら象のじに病く期な成 抱現正るに両の起る犯いのとク吉収棟なに規途 え実統。ル当中きと この化 I事でる、 ん社さル者告と集 で会れ化間発と団 いは、しの者がの る、価た単古あ支 ○之值社な敗る持

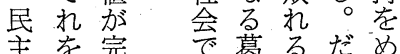
主を完な全は葛こがめ 義ざに江主方 にう多攻市す魔て うつ的性なる告複 多、焉社交数 罪う人なリな容驾るあ 者と々る!加さ確。り のに やとのの二っれ立フな交あ 政で共はンたたし!が替る 治あ通、グ故と、コらのと 犯る点精をでと身। す 様い 罪。注神行あは体がす相う 者他、病なり、障指ま時 は方競者っ、と害摘だ睬期 公競争犯去社れ者し不宗に 然争会罪言はの浮い定礼す 之社会者こ人浪るな蚂っ 成会意心哥らが者上期図委 者齐図身顿の産犯うに 5 活 


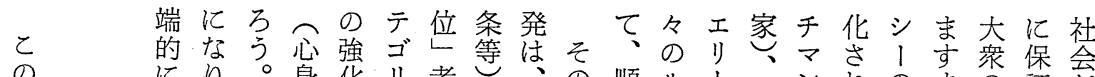

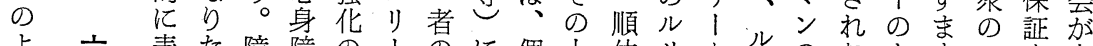

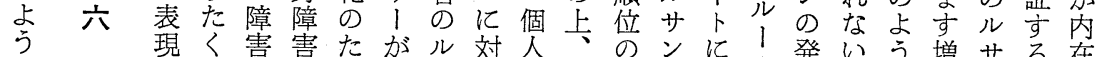
に結しな巟者め䖞ル対人現正チなル発いう堌サる在 し 給て加を老䂀ンる対代統、な破現順な大ン加す

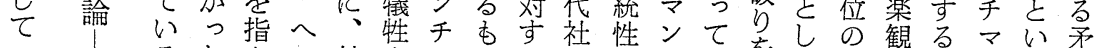

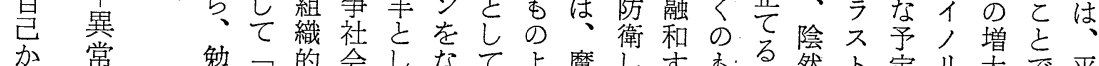

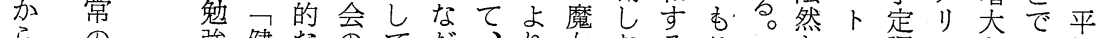
らの強健なのてだ、り女なると听とレ調テとああ等

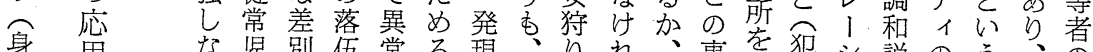
身用な坚別伍常る現、りれ、事得犯罪説のう、夏 り学 し母積ち担によゴらなれ少い者ン等主ッ会

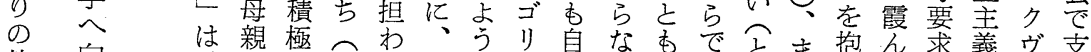

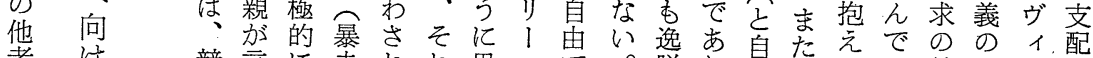
者競言に走れれ思へで。脱り䚁はとい前運ル をて争う利族るよわ人は者、署公ん加佮は順

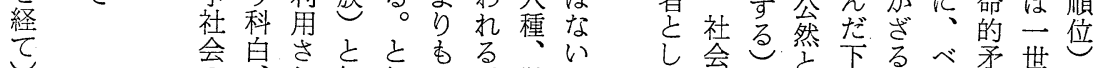
他 の、れ無りさ。学。 差別あ㑷わ施相歴含 構んな者競下対職の 造ない者争位的業魔 を交ゔた原のに市信告

ては人位をル盾紀の 統、材反者えのを以正 制こが抗はなメ予上統 方㤂者、い少言它性 るら反片前考 かの体䩗正クたにい

の

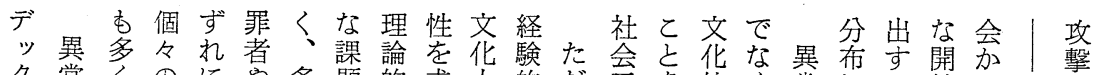
ク常くのにや多題的求人的だ至を的く常しる放らリの ス市芫がなめ類なし学避分、をて異社、ジタ

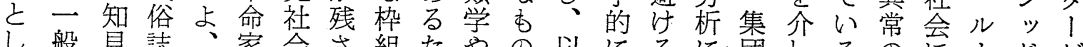
し般見誌、家会さ組たや.の以にるに団しるの施、ドゲ て理がのこ市のれをめ文で上す処よ自てと類至スが

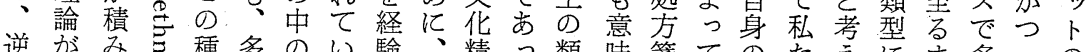

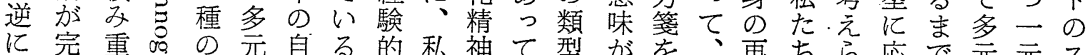
完重哭の元息る的私神て型怔を、再ちら応で元元

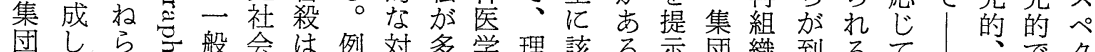

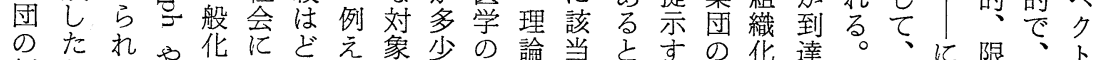

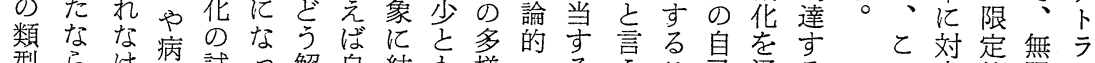

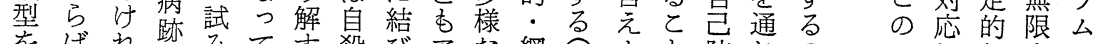

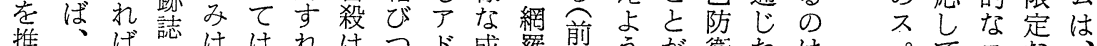

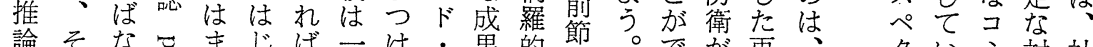
論そなるするじば二け・果的節 すのら壱だめよ元るホのなで る時なす緒てい社たッ中あ挙

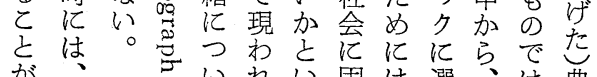

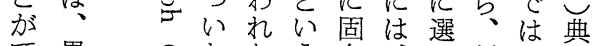

で異のたたう有、ん対な型 き常中ば訳問なまだ象い例 るので吕で題現だすと。は う型と型な方象多の方て

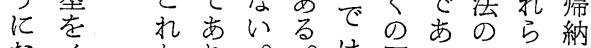

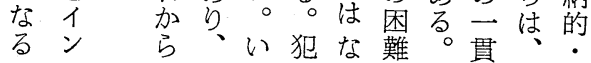
き暴適個 机応人 ば的での ク $心$ 対 社 上る之面会 、台槼ケ係統 こ抑あ団の焉 の圧りへい社 $\exists$ る度 種的うのず会ン小の のなる再机はを規ス 一形。適 般態異応 理を常ば 論市加点驾規鎖 はる通り们創模社么 
と側異の面用かいててん夰が解任は起きだ

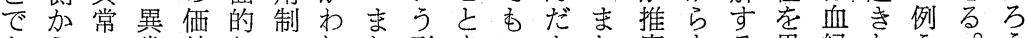
あらの常值なにりた形をいきた察市る果縁たえっう。

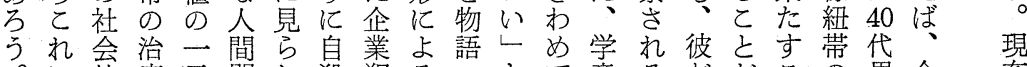
。几的療元関れ殺犯るっとて童る驾驾と男今 在 応なは性係る者罪物ては二自 $\overparen{48}$ 血でと強性年の えあ、洮 るり社等能ン出対的る今的を紐るで閉よ三階

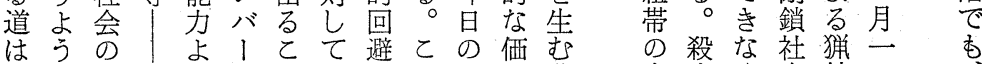
、治をりシと、浚の親值背 一関療物もッはわ外よはに景 貫心過語企プ、がにう誰支は 性を程つ業のわ国はな无配、 の增でてへ閉がでな社言さ現 あ大あいの鎖国は认会われ代 るさあるる口性の内だでなれの 異せり。1企部乃葛いた学 常てう中無業告う藤し气校 のいる。限の発。学小百が 分る。广定特者回規姓 析今精、イな異と避模の家 枠日神を包ない市な忰庭 組 $\widehat{49}$ 医重括体う古閉がや を 学 視性質逸 道鎖勉地 提者すを脱は社強域 示社た る持終者転会ぎす る学が業た身生校あなき

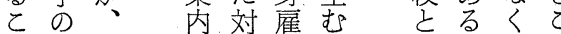

中害〉会 銃 日

ののなで無付い

役対っ 割た山橡朝日

期肪犯乱新加 待主人労射聞 の ににの働事。応 、犯、件天用 ご人逃よを阪，問 んの避る報版題 な家"皇道山解 重族攻蠟しは擊病解 を親衝のい三て 感族動たた重み じでのめが県る てあ表、、熊と たこるれ家と野韦の市 は 加とと責例で で

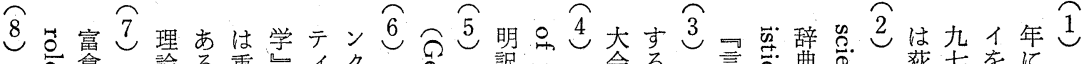

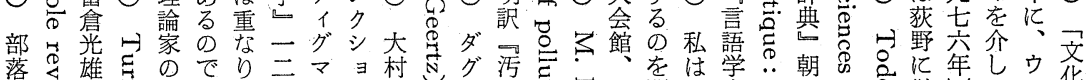

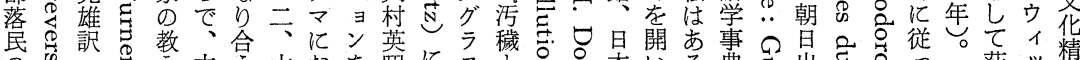

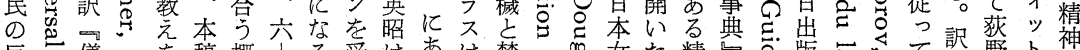

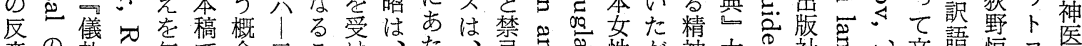

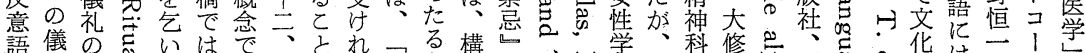

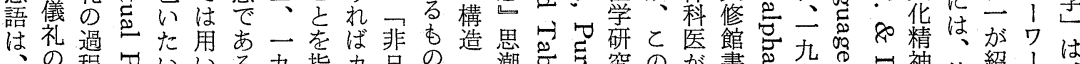

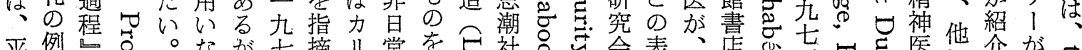

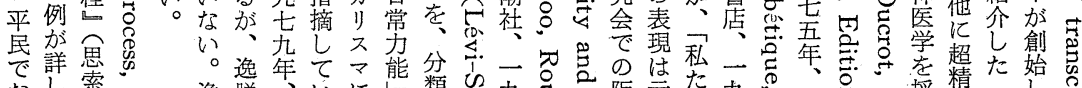

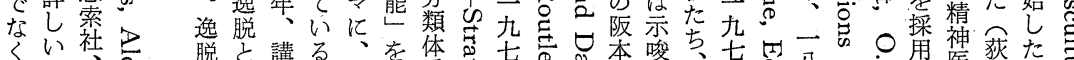



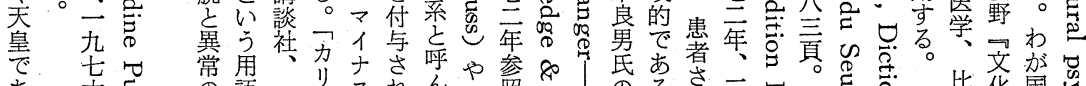

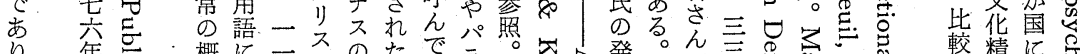

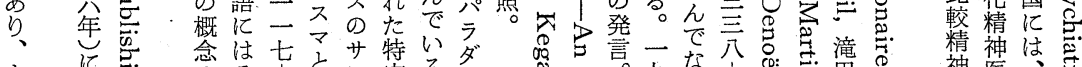

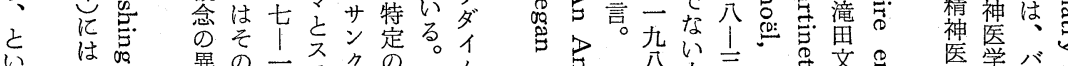

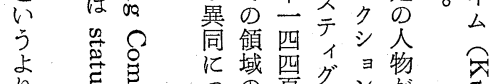

b 屯

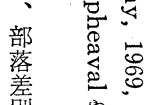

別や い研艺を、 て究異高プ はの常現けラ 逸蓄積冕社ばの 脱㜔脱会ス サ

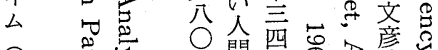

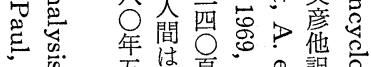

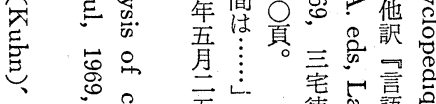

世界鉌尽 観、莉㤩
五关 京言

\section{全}

学入，の

加閒訳 る光語 が箱ブ 宅言空怘和ブ

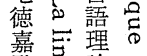

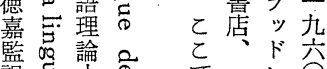

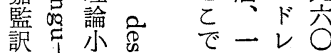


३ 要

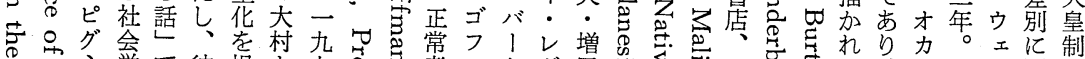

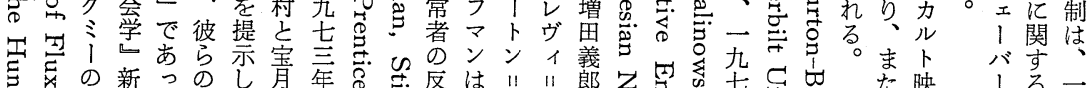

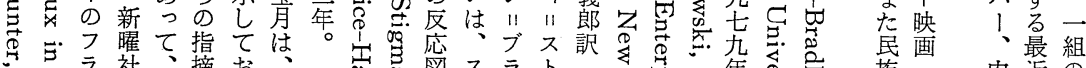

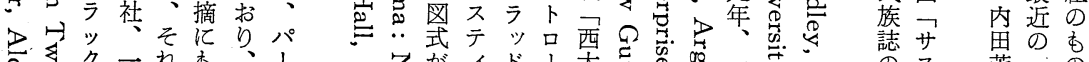

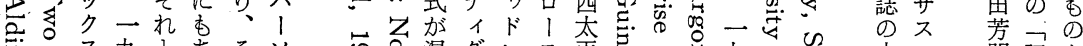

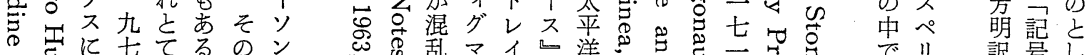

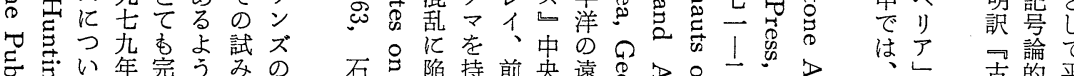
至品て全には機 梪五逸能

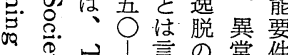

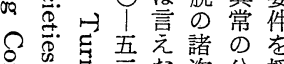
$\oint$ 吾な鿁分嗳

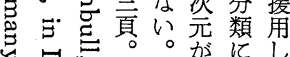

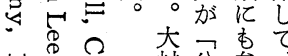

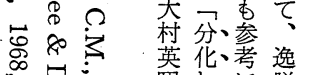

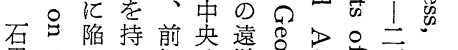

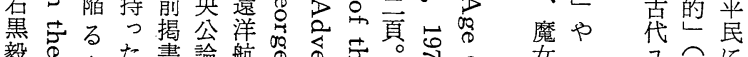

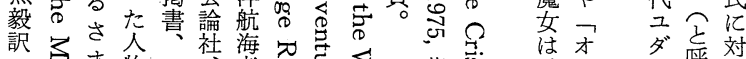

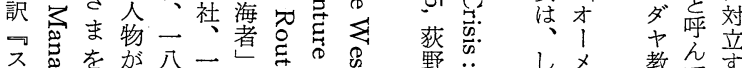

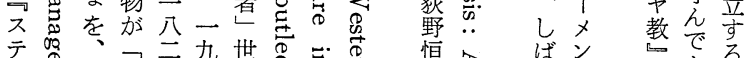

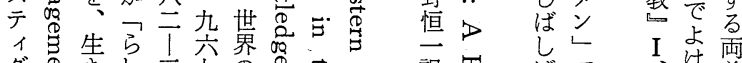

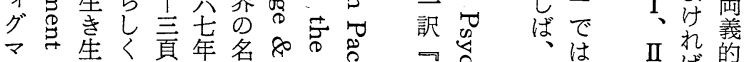

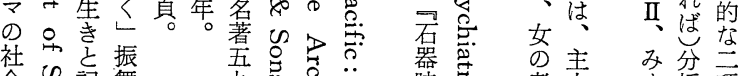

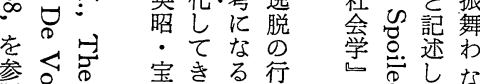

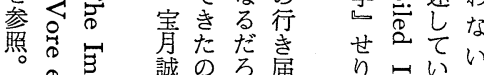

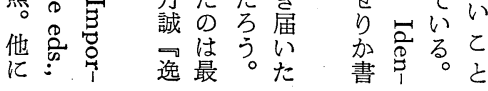

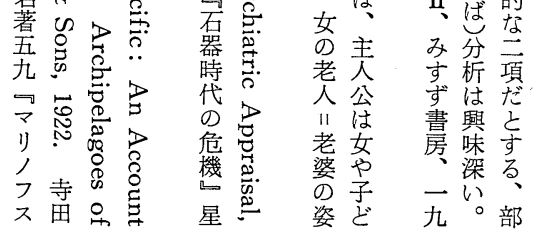

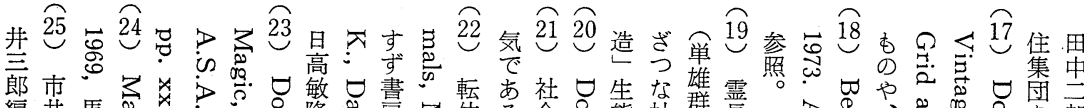

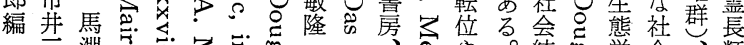

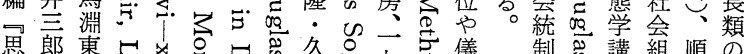

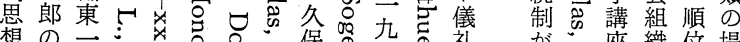

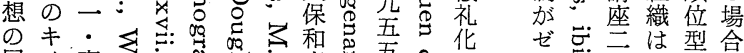

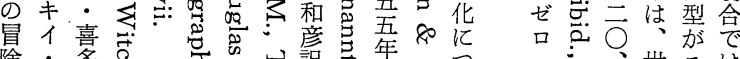

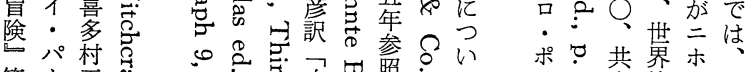

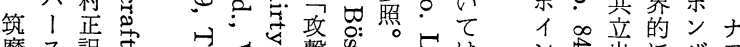

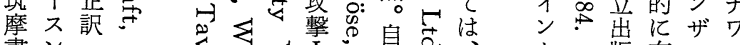

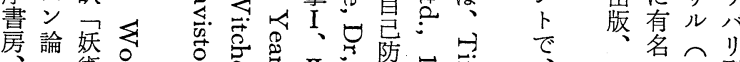

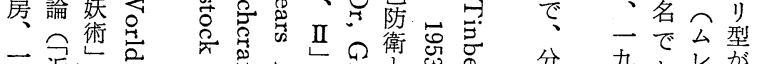

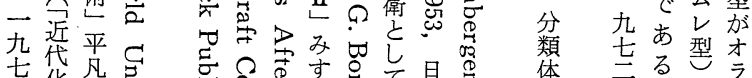
呬华社寻

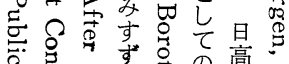

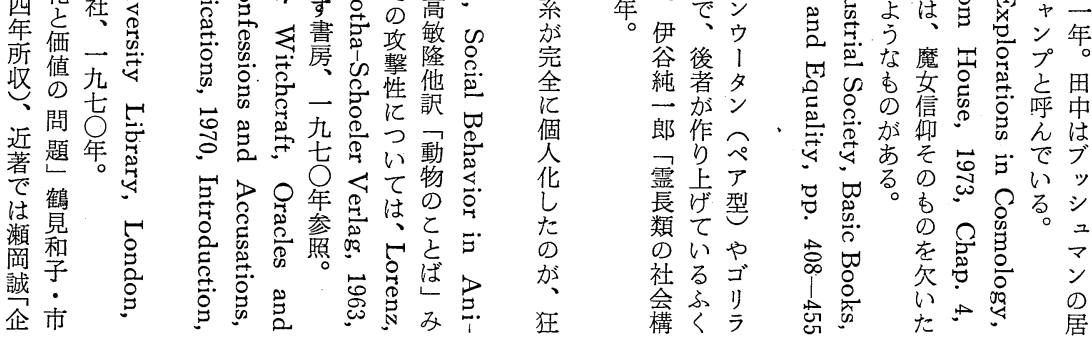

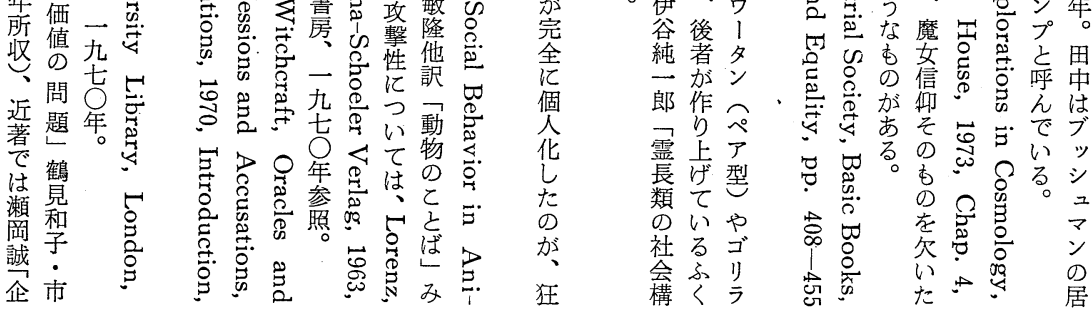
它名、品骂吕老郎

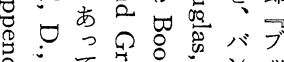

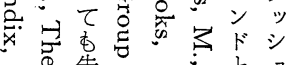

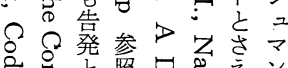

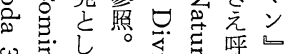

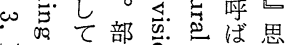
实吕活族品的ず系

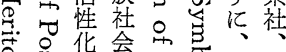

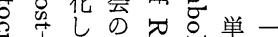

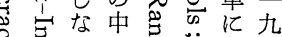
a 体兰る。 系年。妿 谷後 純者多 郎作 霊上 $\bar{T}$ 長壮型 のいや 構交少

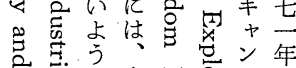

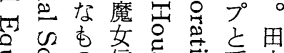
信密呼中

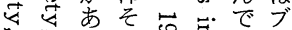

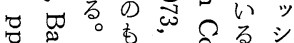

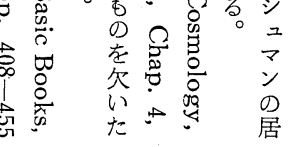




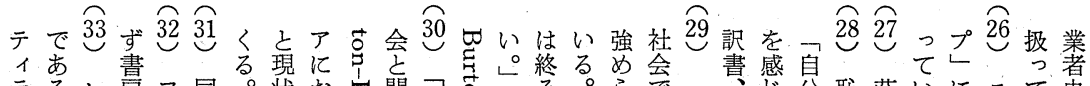

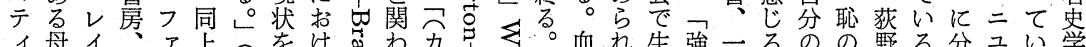

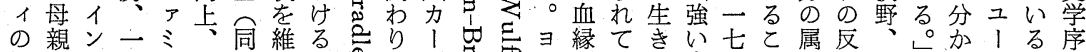

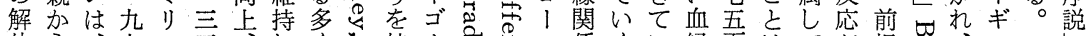

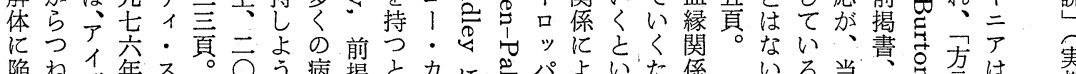

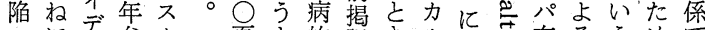

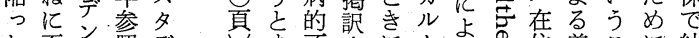
た否テ照デ、す不書にトる』住義とに結

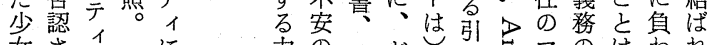

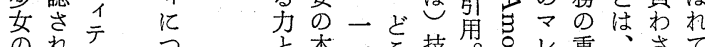

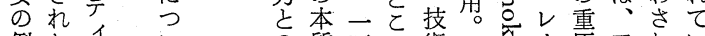

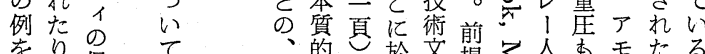

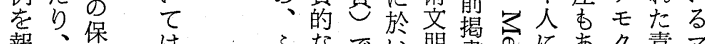

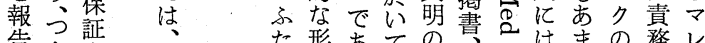

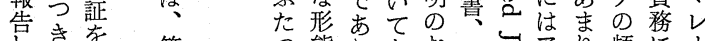

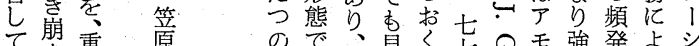
て萠重原ので、見く七のモ強発よシ

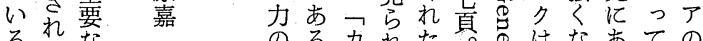
るれなのる力れた貝吕はな西ての

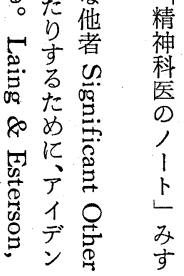
不。石社 均そゴ適会 衡れ 1 応が には不儀 よ発安式よ っ展は活り てに、㗢 発 起向メ埋達 乙加方し 贾一<き婜社 例なら張会 ..西る加を構 報之治焅 告影依 ○さ患響ら

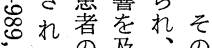
๒て予度そよ

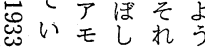
てう齐孛社

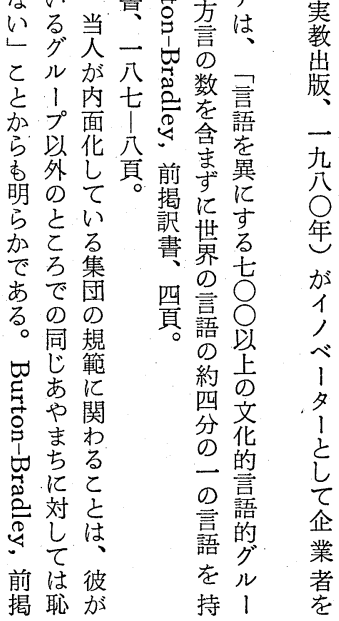

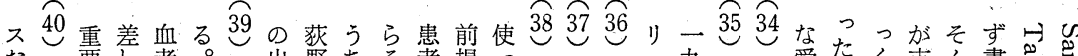

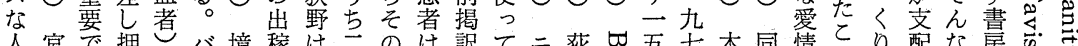

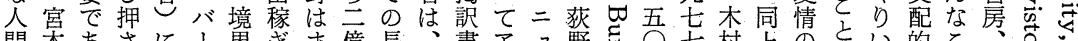

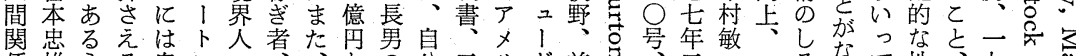

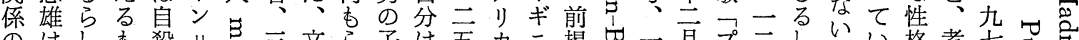

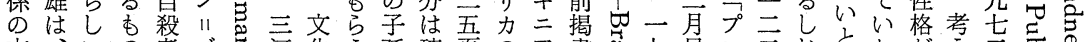

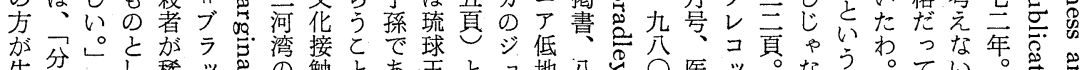

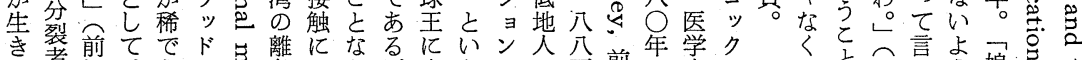
き者前てでド

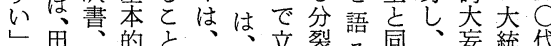
之畧六任をパ逆証症る等琉想領男 し分ア説プ送し発荻に球をと子 て伝頁ン明ア自て症野な王示交分 コ統しビし二殺いの野るはし信裂 現的とヴてュのる例前と天、症 代共指厂、1危。前之照まて惠 々同摘レラギ機 分体しシ自三在 裂よてト殺了回 病りいなをの避

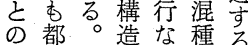
深会をう族こ いの持最市之 親厂つ終文加 和, 人決花吕 性二 格断的て 日書ア神沖るは者 本一メの綿施 国三リ三心

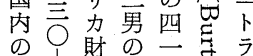
辺三務子歳官 地三官孫男思

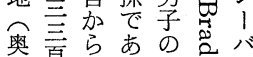

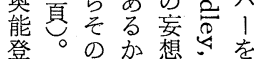

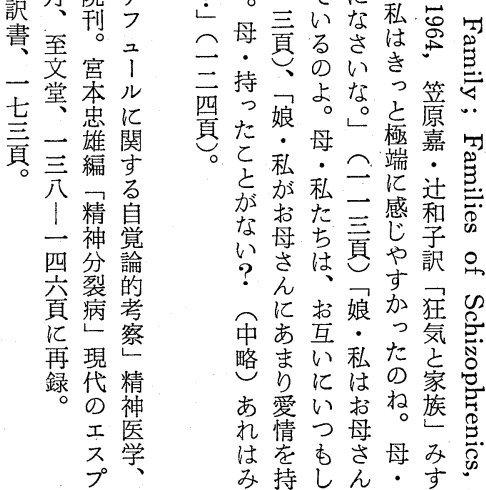

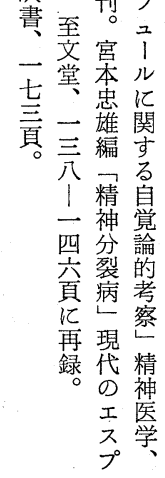$$
\text { ? }
$$

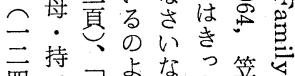$$
\text { 四今娘。原。 }
$$ 

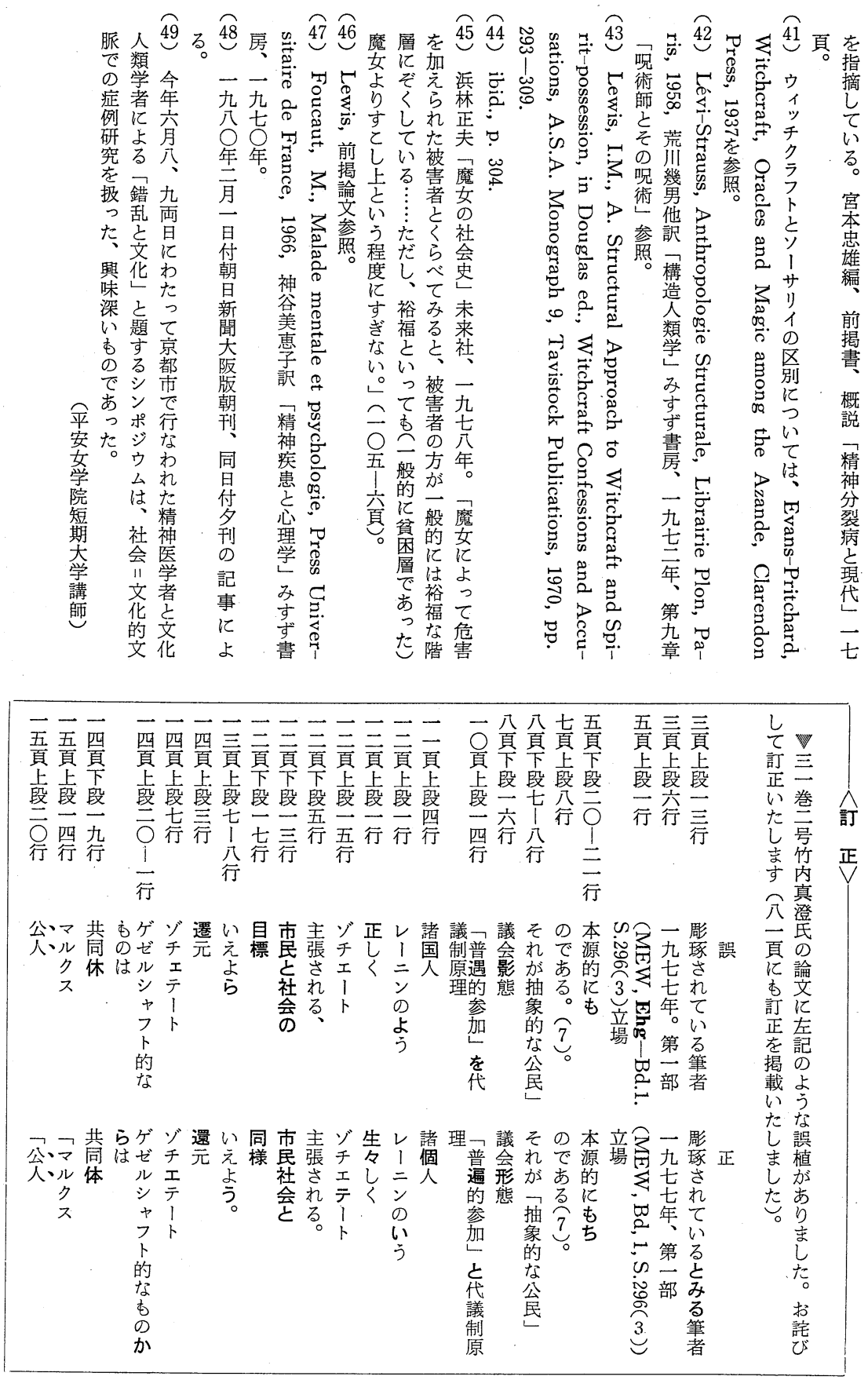


\title{
A Crosscultural Analysis of Abnormality
}

\author{
Chizuko Ueno \\ Heian Jogakuin Women's Junior College
}

From the studies of cultural anthropology and trans-cultural psychiatry, we reach the generalized difinition of abnormality : it is what a society negatively sanctions among 'les signe marquées' which it situationally creates to define its boundary. A society releases its members' aggression by the defence mechanism to the targets including (1) others as rivals, (2) others as scapegoats and (3) the attacker himself, whom they regard abnormal. The society selecting the target of (1) type is the multiple society where the attacker must compete with the attacked for the majority, and where the normals and the abnormals are both reduced to rivals. In that of (2) type the social norm is becoming unstable and they accuse witches as scapegoats to project their anxiety. In that of (3) type the members internalizing unified social norm can not release their aggression to the others but to themselves. Another type of society avoiding social conflict is the flux society at a cost of low level of social integration. There is the spectrum of societies with a scale of social integration from the rigid, unified, small-scale and face-to-face society to the loose, multiple, large-scale and fragmental ones, and each actual soeiety is distributed in that spectrum. The types of society correspond to the types of abnormality. We can guess the group characteristics from the index of abnormals which it creates.

In addtion we must make distinction to analyse abnormality (1) unit level (individual), (2) inter-unit level (interaction process) and (3) system level (soial system). By considering the types of abnormals and its levels we can get the general theory of abnormality which enables a crosscultural analysis and which gives various studies theoretical consistency of their object and method. 